\title{
19. PLIOCENE-PLEISTOCENE CARBON ISOTOPE RECORD, SITE 586, ONTONG JAVA PLATEAU ${ }^{1}$
}

\author{
Jill M. Whitman ${ }^{2,3}$ and Wolf H. Berger ${ }^{2}$
}

\begin{abstract}
Oceanographic changes in the western equatorial Pacific during the past $6 \mathrm{~m} . \mathrm{y}$. are inferred from carbon isotopic analyses of planktonic and benthic foraminifers from Ontong Java Plateau (DSDP Site 586). Sample spacing is $1.5 \mathrm{~m}$ (ca. $35,000-75,000 \mathrm{yr}$ ). An overall trend of $\delta^{13} \mathrm{C}$ toward lighter values is evident for the last $5 \mathrm{~m}$.y. in all four foraminiferal taxa analyzed $(G$. sacculifer, Pulleniatina, $P$. wuellerstorfi, and $O$. umbonatus). This trend is interpreted as an enrichment of the global ocean with ${ }^{12} \mathrm{C}$, because of the addition of carbon from organic carbon reservoirs (or lack of removal of carbon to such reservoirs), as a consequence of an overall drop in sea level. Differences between shallow- and deep-water $\delta^{13} \mathrm{C}$ decrease slightly during this time interval, suggesting a moderate drop in productivity. This drop is not sufficient to explain the drop in sedimentation rate, however, much of which apparently must be ascribed to winnowing effects.

A marked convergence in the $\delta^{13} \mathrm{C}$ values of planktonic taxa exists within the last $2 \mathrm{~m}$.y. We propose that this convergence indicates nutrient depletion in thermocline waters, caused by the vigorous removal of phosphate in marginal upwelling regions, or by the stripping of intermediate waters in their source regions. No large shifts are seen in the carbon isotope record of the last $6 \mathrm{~m} . \mathrm{y}$., in contrast to the oxygen isotope record. Some indication of cyclicity is present, with a period between 0.5 and $1.0 \mathrm{~m} . \mathrm{y}$. (especially in the earlier portion of the record).
\end{abstract}

\section{INTRODUCTION}

The last 6 m.y. of ocean history are characterized by marked changes in both deep- and shallow-water circulation, in response to climatic and geochemical changes resulting from mountain building and regression, from the closing of the Middle American Seaway, and from ice buildup in the southern and northern polar regions. The response of the carbon cycle of the ocean to these global changes is of considerable interest. This cycle is an integral part of climatic change, and much of the record in the deep sea is directly tied to the carbon cycle.

One place that is ideally suited for studying the record of the ocean's carbon cycle is the Ontong Java Plateau in the western equatorial Pacific. In this region, far from the influence of continental margins and other special conditions, the signals recorded in biogenic sediments have a strong global component. Fluctuations in equatorial upwelling, a phenomenon of global significance, are represented within the sediments on the northernmost portion of the plateau, from which our samples originate.

We focus on the stable isotope record of planktonic and benthic foraminifers from this region, using cores recovered at Site 586 of Deep Sea Drilling Project (DSDP) Leg 89 (Shipboard Scientific Party, 1986). Site 586 neighbors Site 289, which was drilled during DSDP Leg 30 (Andrews, Packham, et al., 1975). It is but a short distance from Site 806, drilled during Ocean Drilling Program (ODP) Leg 130 (Kroenke, Berger, Janecek, et al., 1991), so that results can be readily compared among these sites.

The results of the oxygen isotope analyses have been published (Whitman and Berger, 1992). Here we present the carbon isotope data and discuss their implications. The taxa we have analyzed are Globigerinoides sacculifer, Pulleniatina spp., Planulina wuellerstorfi, and Oridorsalis umbonatus. G. sacculifer is a shallow-water species monitoring the mixed layer, Pulleniatina lives in the uppermost

\footnotetext{
${ }^{1}$ Berger, W.H., Kroenke, L.W., Mayer, L.A., et al., 1993. Proc, ODP, Sci. Results, 130: College Station, TX (Ocean Drilling Program).

${ }^{2}$ Scripps Institution of Oceanography, University of California, San Diego, La Jolla, Ca 92093-0212, U.S.A.

${ }^{3}$ Present address: Department of Earth Sciences, Pacific Lutheran University, Tacoma, WA 98447 , U.S.A.
}

thermocline, $P$. wuellerstorfi and $O$. umbonatus live on the seafloor and record changes in the chemistry of the water there.

\section{SETTING AND STRATIGRAPHY}

The Ontong Java Plateau is a Texas-sized, elevated region east of New Guinea, bearing a layer-cake cover of calcareous sediments more than $1 \mathrm{~km}$ thick in the shallower portions (Berger and Johnson, 1976). The plateau has long been a favored region for paleoceanographic investigation, yielding important information on Pleistocene oxygen isotope cycles (Shackleton and Opdyke, 1973, 1976). It has been studied for processes of carbonate sedimentation (Johnson et al., 1977; Berger and Killingley, 1982) and for late Pleistocene paleoceanography (Berger et al., 1987; Hebbeln et al., 1990; Wu et al., 1990; Herguera and Berger, 1991). Also, this area has attracted four different drilling expeditions (DSDP Leg 7, Winterer, Riedel, et al., 1971; DSDP Leg 30, Andrews, Packham, et al., 1975; DSDP Leg 89, Shipboard Scientific Party, 1986; and ODPLeg 130, Kroenke, Berger, Janecek, et al., 1991).

Site 586 is close to the equator, at a depth of $2218 \mathrm{~m}$ (Fig. 1). It is located on the northeastern upper slope of Ontong Java Plateau $\left(00^{\circ} 29.84^{\prime} \mathrm{S}, 158^{\circ} 29.89^{\prime} \mathrm{E}\right)$, about $1 \mathrm{nmi}$ northwest of DSDP Site 289. Our samples derive from the upper $195 \mathrm{~m}$ of sediments, recovered by hydraulic piston coring in Holes 586 and 586A. They constitute a continuous and undisturbed record of the last 6 m.y., from the latest Miocene to the present. Sedimentation rates are quite high, ranging from about $40 \mathrm{~m} / \mathrm{m} . \mathrm{y}$. in the lower portion of the section studied to $20 \mathrm{~m} / \mathrm{m}$.y. in the upper part. At the depth $(2200 \mathrm{~m})$ and location (equator) of Site 586, the Ontong Java Plateau is bathed in General Pacific Deep Water, about $500-700 \mathrm{~m}$ below the Intermediate Waters of the Pacific (Reid, 1965; Dietrich et al., 1980). The site is located well above the present depth of the foraminifer lysocline in this region (3300-3400 m; Berger et al., 1982; Wu and Berger, 1989). Thus, the isotopic record should be largely unaffected by differential dissolution, and should contain an excellent paleoceanographic record for the late Neogene.

The sequence studied here is part of a single lithologic unit (Shipboard Scientific Party, 1986), described as pale green to white foraminifer-nannofossil ooze and foraminifer-bearing nannofossil ooze (Fig. 2). The sediments of the Pleistocene $(0-38 \mathrm{~m})$ contain a larger percentage of foraminifers (up to $60 \%$ ) compared with those 


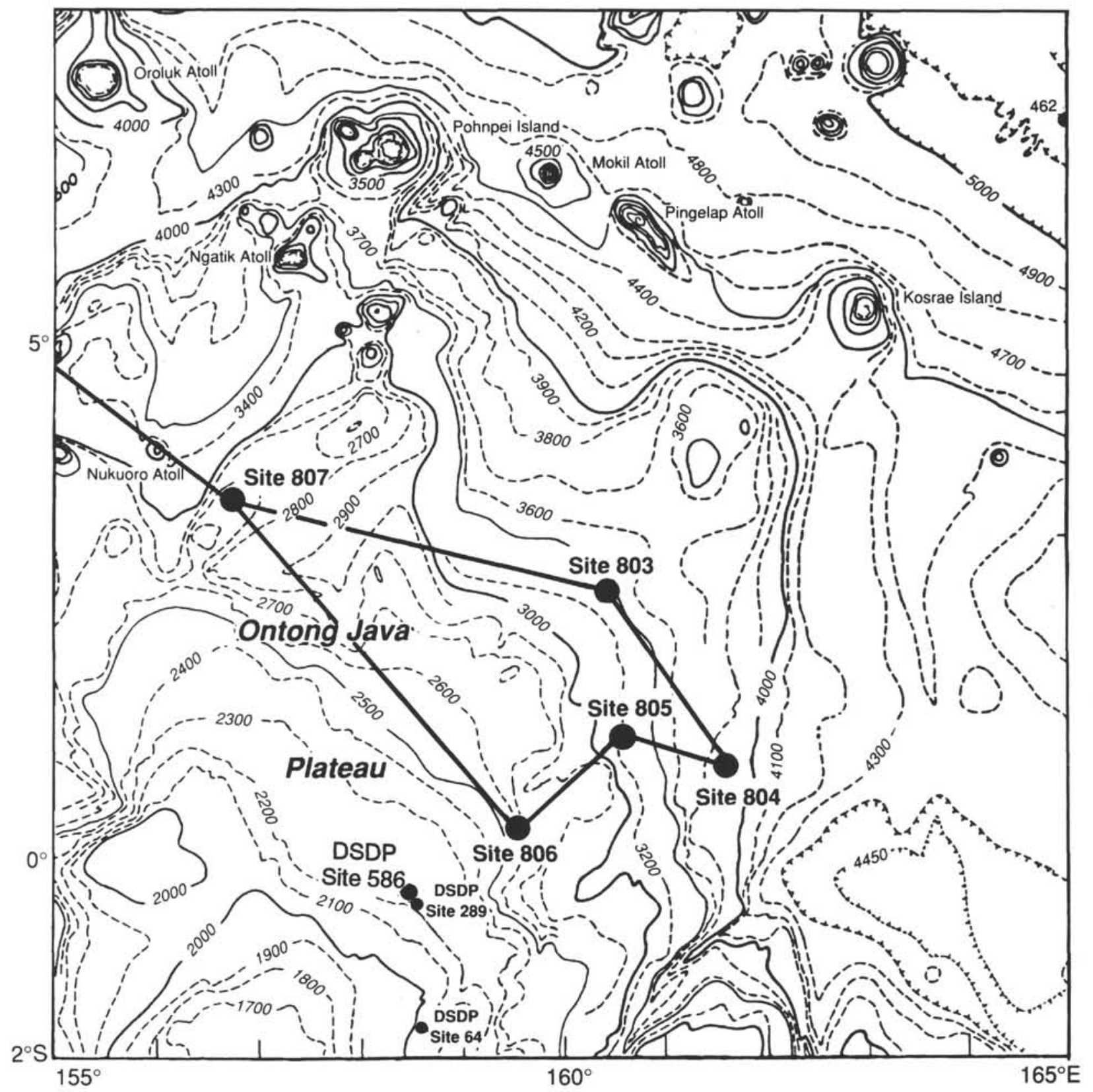

Figure 1. Location of DSDP Site 586 in relation to ODP Leg 130 sites. Bathymetry after Mammerickx and Smith (1985).

of the Pliocene $(<20 \%)$. The remainder consists mainly of nannofossils. Biogenic siliceous components (radiolarians and diatoms) are present in minor amounts $(<5 \%)$. Also, a small contribution of nonbiogenic material (volcanic glass, zeolites, pyrite) was observed throughout the section.

The age assignments (Fig. 2) are based on magneto- and biostratigraphy, as described in Whitman and Berger (1992). The base of the Brunhes Chron is taken to be 15.4 meters below seafloor ( $\mathrm{mbsf}$ ) in Hole 586. The age of the event is taken as $0.73 \mathrm{Ma}$, which is the conventional assignment (Shackleton and Opdyke, 1973). The age is probably greater (Shackleton et al., 1990; Berger et al., this volume; Yasuda et al., this volume); however, the data presented here have no bearing on the question and the conclusions are little affected by this uncertainty. Biostratigraphic control is based both on shipboard analyses of core-catcher samples (Shipboard Scientific Party, 1986) and on biostratigraphic refinements from ranges of certain foraminifers, using additional samples for greater resolution (Whitman, 1989). Ages of first and last appearances were taken from Berggren et al. (1985). The age control points for this study are listed in Table 1. The resulting sedimentation rates (Fig. 2) indicate that the sampling interval of $1.5 \mathrm{~m}$ corresponds to $70 \mathrm{k} . \mathrm{y}$. in the late Pliocene and Pleistocene; to $43 \mathrm{k} . \mathrm{y}$. in the latest early Pliocene; and to $35 \mathrm{k} . \mathrm{y}$. in the early Pliocene and latest late Miocene.

\section{MATERIALS AND METHODS}

\section{Sample Preparation and Isotopic Analyses}

Bulk sediment samples $\left(10 \mathrm{~cm}^{3}\right)$, obtained from the hydraulic piston cores of Site 586 at $1.5-\mathrm{m}$ intervals between 0 and $195 \mathrm{~m}$, were dried and weighed. They were soaked overnight in a buffered Calgon 


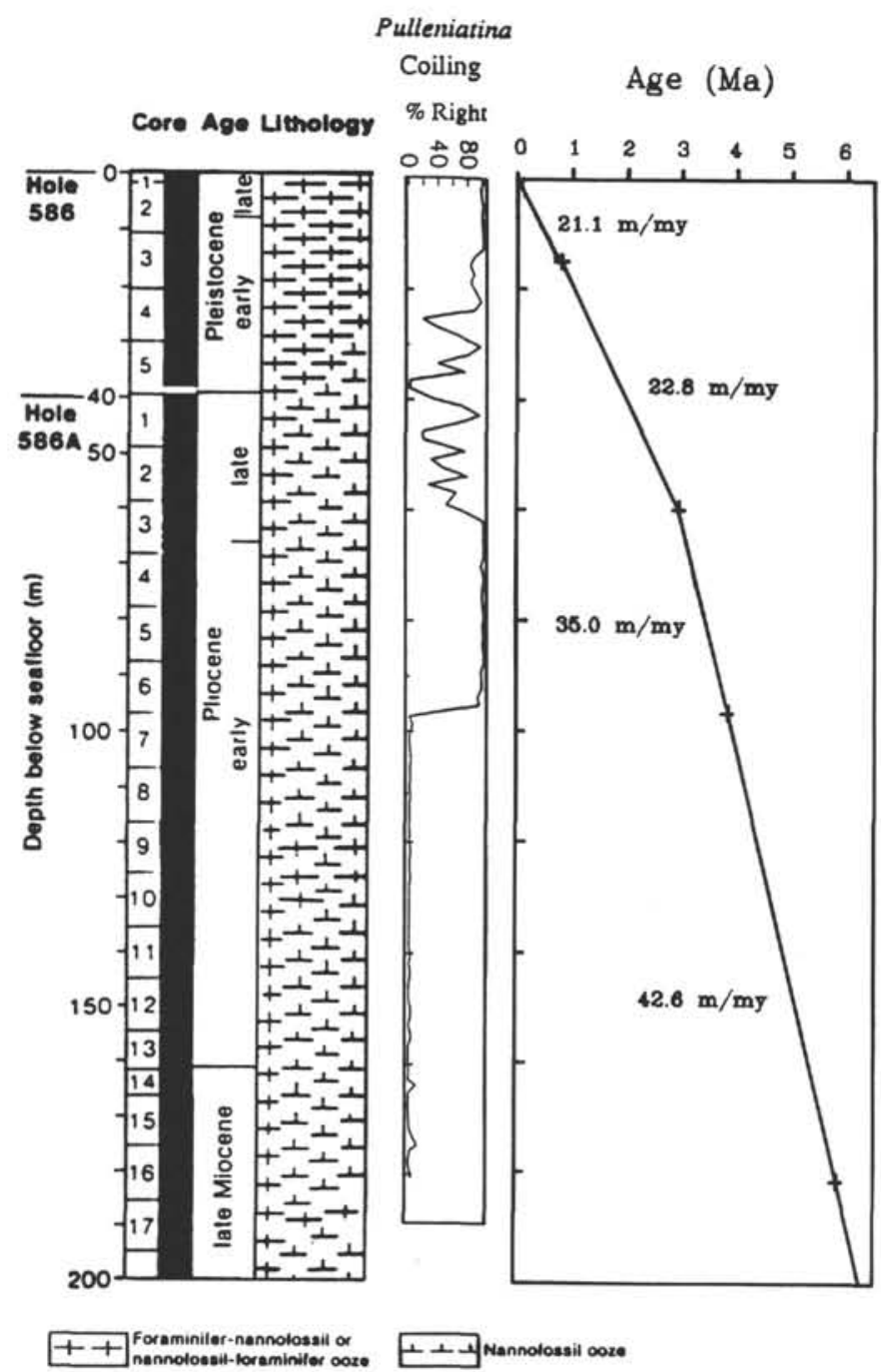

Figure 2. Stratigraphy of Site 586 and age model adopted here (from Whitman and Berger, 1992).

solution to facilitate disaggregation. The sediment was then washed in deionized water, oxidized in $3.5 \% \mathrm{H}_{2} \mathrm{O}_{2}$, ultrasonified to complete the disaggregation, and wet sieved at 63,149 , and $250 \mu \mathrm{m}$ (for grain-size analysis). The grain-size data are presented in Appendix A. The total benthic foraminiferal population from each sample in the size fraction $>250 \mu \mathrm{m}$ was picked, and the total as well as the percentage of certain species and genera within the total benthic population were counted: $P$. wuellerstorfi, $O$. umbonatus, and all the specimens in the genus Uvigerina. These data are listed in Appendix B.

Stable isotopes were measured on four taxa of foraminifers, as mentioned in the "Introduction" section (this chapter). The planktonic specimens were picked from the size fraction $355-425 \mu \mathrm{m}$ and the benthic species from the fraction $>250 \mu \mathrm{m}$. The narrow size fraction for the planktonic foraminifers was used to minimize interference from changing depth ranges and changing vital effects during the life cycle of the species (Berger et al., 1978). For benthic foraminifers, we did not feel it was necessary to take this precaution, as no evidence exists that size influences composition (Dunbar and Wefer, 1984). The sample size for isotopic measurement was $250-1000 \mu \mathrm{g}$, depending upon the availability of specimens; planktonic samples usually contained 15-25 individuals, and benthic samples 5-10 individuals. In some samples, insufficient numbers of one or both of the benthic
Table 1. Age control points/events, Site 586.

\begin{tabular}{|c|c|c|c|}
\hline $\begin{array}{l}\text { Depth } \\
\text { (mbsf) }\end{array}$ & $\begin{array}{l}\text { Age* } \\
(\mathrm{Ma})\end{array}$ & Event & From interpolation \\
\hline 0.0 & 0.0 & Top of core & \\
\hline$\bullet+15.4$ & 0.73 & $\begin{array}{l}\text { Brunhes/Matuyama boundary } \\
\text { (Barton and Bloemendahl, 1986) }\end{array}$ & \\
\hline 36.6 & 1.66 & & Pliocene/Pleistocene boundiary \\
\hline 55.0 & 2.47 & & Matuyama/Gauss boundary \\
\hline$* 64.8 \mathrm{~m}$ & 29 & LAD G. altispira & \\
\hline 85.8 & 3.4 & & Gauss/Gilbert boundary \\
\hline$* * 96.3$ & 3.8 & S/D coiling change Pulleniatina & \\
\hline 160.2 & 5.3 & & Miocene/Pliocene boundary \\
\hline$* * 181.5$ & 5.8 & FAD Pulleniatina & \\
\hline
\end{tabular}

-Dates based on Berggren et al. (1985).

**Indicates age control points identified in Site 586 sediments. FAD = first appearance datum, LAD $=$ last appearance datum, and $\mathrm{S} / \mathrm{D}=$ sinistral/dextral coiling shift.

species were present for analysis. In a few instances, duplicate measurements were made on one of the planktonic taxa. A VG Micromass $602 \mathrm{C}$ mass spectrometer was used to make the measurements in the conventional fashion (for details, see Whitman and Berger, 1992). The isotopic data are presented in Appendix C.

\section{Interpretation of Carbon Isotopes}

We take the $\delta^{13} \mathrm{C}$ values measured as reflecting the isotopic composition of seawater, in the main. This interpretation rests on previous work on surface sediments of Ontong Java Plateau (Berger et al., 1978; Vincent et al., 1981). It appears, from these studies, that moderately large $G$. sacculifer and Pulleniatina will yield $\delta^{13} \mathrm{C}$ values that reflect the composition of the surrounding seawater (notwithstanding the vital effects that undoubtedly play a role in $G$. sacculifer; see Spero and Williams, 1988). Regarding $\delta^{13} \mathrm{C}$ in benthic foraminifers, $P$. wuellerstorfi is thought to be an especially good recorder of carbon isotopes in deep water (Woodruff et al., 1980; Graham et al., 1981; Vincent et al., 1981; Woodruff and Savin, 1985; summary in Wefer and Berger, 1991). This species has an epibenthic habitat, which avoids interference from interstitial waters (Grossman, 1987; Lutze and Thiel, 1989; McCorkle et al., 1990).

Changes in the $\delta^{13} \mathrm{C}$ values of planktonic and benthic foraminifers largely reflect the shifting of organic matter from one reservoir to another. Organic carbon is depleted in ${ }^{13} \mathrm{C}$; building up a reservoir, therefore, enriches the ocean in the heavy isotope, and vice versa (Tappan, 1968; Fischer and Arthur, 1977; Shackleton, 1977; Vincent and Berger, 1985; Woodruff et al., 1985; Raymo et al., 1989). The glacial-to-interglacial contrast for the last cycle, for example, is between $0.4 \%$ and $0.5 \%$ (Berger and Keir, 1984; Herguera et al., 1992), which corresponds to a transfer of carbon of approximately one atmospheric carbon mass (ACM) in and out of organic pools.

The surface waters are enriched in ${ }^{13} \mathrm{C}$, as ${ }^{12} \mathrm{C}$ is removed preferentially by the sinking of organic matter out of the photic zone. The contrast between shallow and deep waters is typically between $1 \%$ and $2 \%$ (Fig. $3 \mathrm{~A}$ ). The difference in $\delta^{13 \mathrm{C}}$ between planktonic and benthic foraminifers is a measure of the efficiency of this biological pump (Broecker, 1973, 1982): a greater difference in $\delta^{13} \mathrm{C}$ points to a greater nutrient concentration, and hence implies greater productivity, other factors being equal (Shackleton et al., 1983a; Boyle, 1988a, $1988 \mathrm{~b}$ ). The distribution of oxygen utilization and of nutrients in the oceans (phosphate and nitrate in particular) parallels the trends of ${ }^{12} \mathrm{C} /{ }^{13} \mathrm{C}$ in the oceans, as oxygen, phosphate, and nitrate all are involved in the internal carbon cycle (Kroopnick, 1985). Conversion coefficients between the different parameters, based on the Redfield ratios or on regressions, are given by Kroopnick (1985) and in Berger and Spitzy (1988).

As deep waters move away from their sites of formation (and source of oxygen), the oxygen concentration continues to decrease 
A $\Sigma \mathrm{CO}_{2}(\mu \mathrm{MOLE} / \mathrm{KG})$

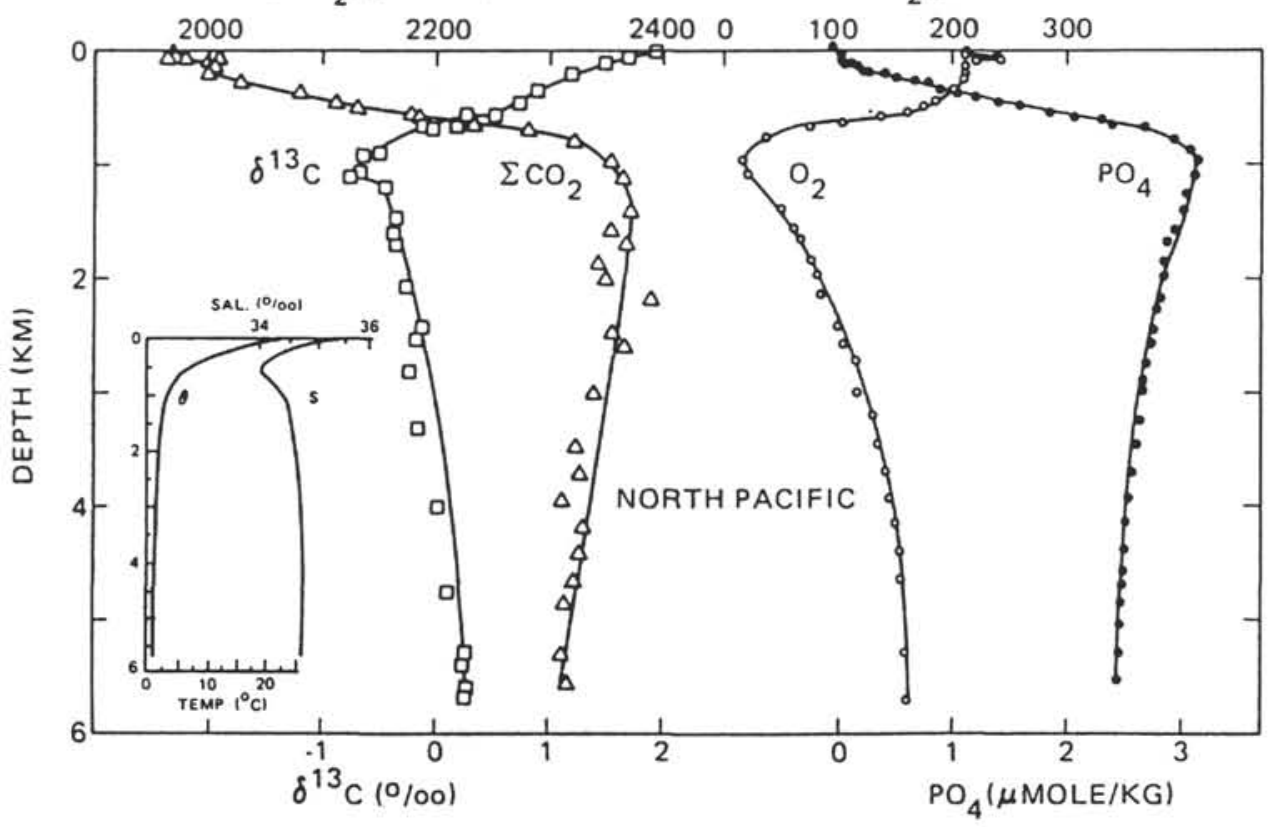

B PACIFIC ATLANTIC
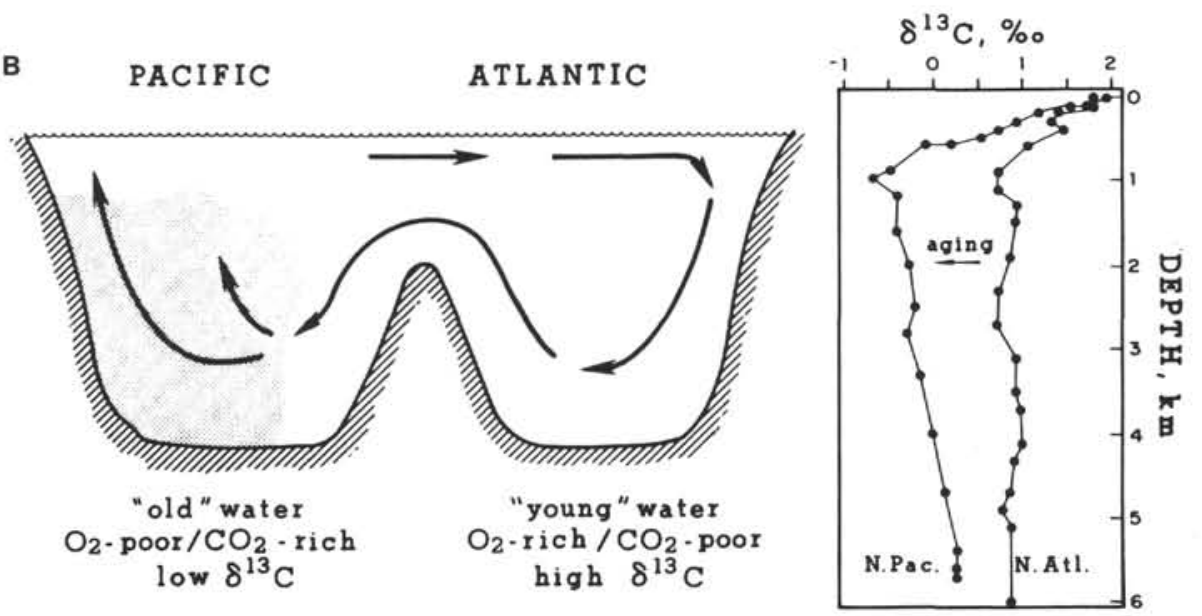

Figure 3. Internal fractionation of carbon isotopes in the ocean. A. Evidence for preferential removal of ${ }^{12} \mathrm{C}$ from surface waters by biological pumping (from Kroopnick, 1985). B. Basic pattern of water exchange between the Pacific and Atlantic oceans, and resulting $\delta^{13} \mathrm{C}$ distribution in deep waters (from Berger and Vincent, 1986).

because of the continued combustion of organic matter. Thus, the older bottom waters of the Pacific have high values of apparent oxygen utilization (AOU; i.e., the difference between observed oxygen content and saturation values), and low values of $\delta^{13} \mathrm{C}$ of the dissolved $\mathrm{CO}_{2}$. The overall difference in the $\delta^{13} \mathrm{C}$ values of deep Pacific and deep Atlantic waters reflects the present asymmetry in bottom-water production, and this asymmetry chan ges through time (Vincent et al., 1980; Shackleton et al., 1983b; Miller and Fairbanks, 1985; Keir, 1988; Raymo et al., 1990). The resulting fractionation of the isotopes of carbon between the ocean basins is an example of interbasin biological fractionation, well-known for phosphate, nitrate, and silica (Sverdrup et al., 1942; Redfield et al., 1963) (Fig. 3B). The present contrast of deep-water values between Atlantic and Pacific is typically near $1 \%$ (Fig. 3B).

From this brief outline of controls on $\delta^{13} \mathrm{C}$ patterns in the ocean, it is apparent that a number of different factors must be considered simultaneously when interpreting carbon isotope values in foraminifers. As a rule of thumb, when the benthic and planktonic taxa covary, it reflects a global change in the composition of the oceanic carbon reservoir (from external exchange); however, when the two signals record opposite trends, it is likely a record of changing nutrient content in deep waters (driving internal fractionation activity).

\section{RESULTS}

\section{Overview: Stable Isotopes vs. Depth-in-Hole}

The stable isotope data for Site 586 are plotted against depth in Figure 4. Oxygen isotope data are from Whitman and Berger (1992); carbon isotopes are listed in Appendix C. The oxygen isotopes (Fig. 4A) show clearly different values for the four taxa; averages are $-1.31 \%,-0.99 \%, 2.73 \%$, and $3.38 \%$ for G. sacculifer, Pulleniatina, $P$. wuellerstorfi, and $O$. umbonatus, respectively. A difference of $4 \%$ 

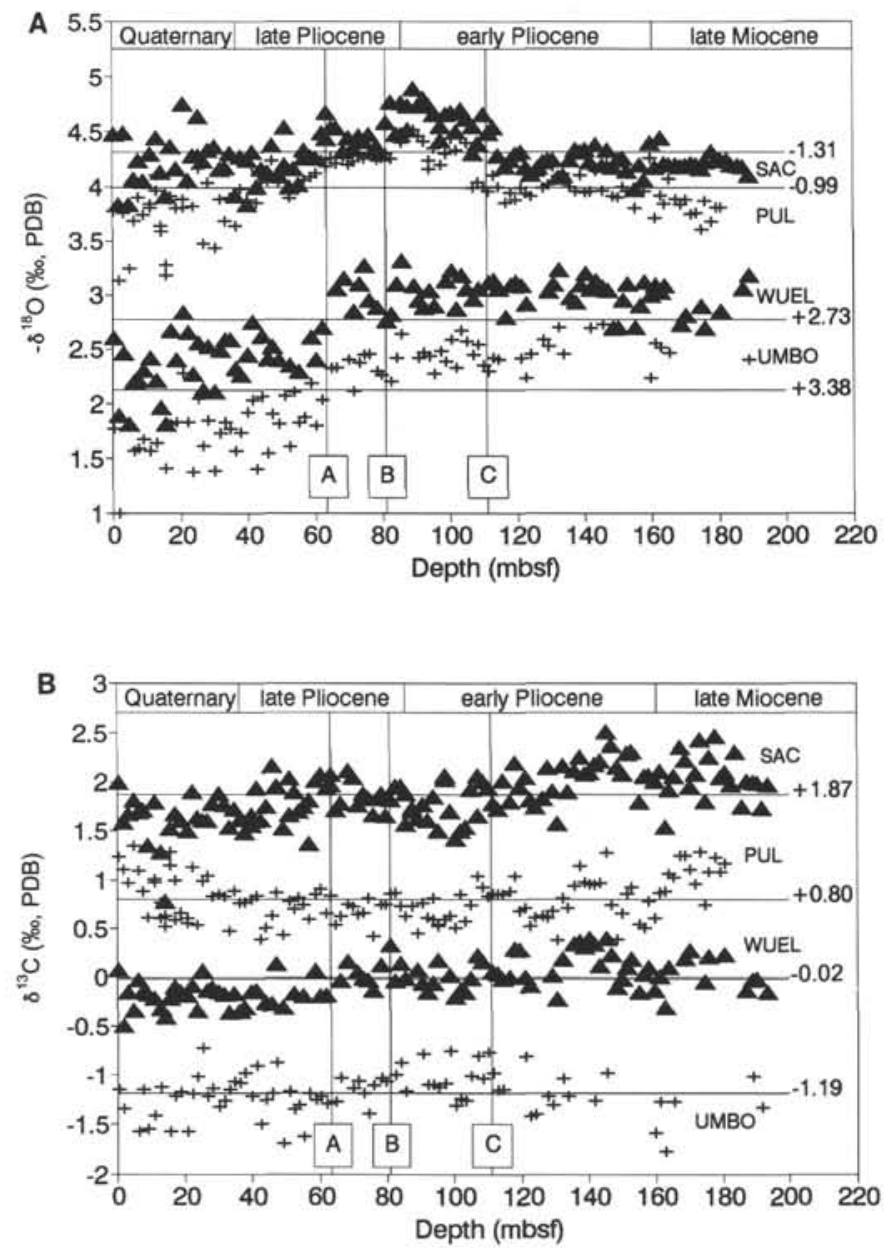

Figure 4. Stable isotope stratigraphy for Site 586, plotted within ODP depth frame. A. Oxygen isotopes. B. Carbon isotopes. Lines labeled A, B, and C are events seen in the oxygen isotope record (see text). $\mathrm{SAC}=G$. sacculifer, $\mathrm{PUL}$ $=$ Pulleniatina, $\mathrm{WUEL}=P$. wuellerstorfi, and $\mathrm{UMBO}=O$. umbonatus. The average value for each species is marked by a horizontal line labeled with the value at right.

between $G$. sacculifer and $P$. wuellerstorfi corresponds to a temperature difference of roughly $20^{\circ} \mathrm{C}$. The exact value depends on evaporation-precipitation effects and is not readily determined. Clearly, the difference is increased within the Quaternary (4.3\%o; Whitman and Berger, 1992). This is not enough, however, to account for the present temperature difference of $27^{\circ} \mathrm{C}$, for which about $5.4 \%$ are expected. The difference of $5.05 \%$ between $G$. sacculifer and $O$. umbonatus comes close to this expected value (a change of $1^{\circ} \mathrm{C}$ corresponding to change in $\delta^{18} \mathrm{O}$ of ca. $0.2 \%$ in the present ocean). Thus, O. umbonatus is closer to equilibrium with seawater than is $P$. wuellerstorfi, as concerns the oxygen isotope ratio.

Substantial shifts are seen in the isotopic records; these are labeled as Events "A," "B," and "C." Event A (at 63.5 mbsf) marks a rapid and drastic change in benthic oxygen isotope values, signaling ice buildup or cooling at depth or both. It is the dominant feature in our record. The age of this event is $2.87 \mathrm{Ma}$ in our age model, which agrees well with the age of a major cooling trend recorded at other sites in the global ocean (Keigwin, 1986; Loubere and Moss, 1986; Sarnthein and Fenner, 1988; Sarnthein and Tiedemann, 1988; Curry and Miller, 1990; Tiedemann, 1991; Whitman and Berger, 1992). The change is less pronounced in the planktonic record than in the benthic one, though it is still present. Thus, a combination of ice buildup and deep-water cooling is indicated. (Jansen et al. [1990] show the onset of ice-rafting at 2.6 Ma in the Norwegian Sea.) Cooling is on the order of $2^{\circ}-3^{\circ} \mathrm{C}$, judging from the trends seen in these data.

Event B (at $81 \mathrm{mbsf}$ ) marks a change in planktonic $\delta^{18} \mathrm{O}$ values, without a corresponding change in the benthic values. The age of this event is $3.36 \mathrm{Ma}$ in our age model. Substantial changes in surface temperature in this region of very high temperatures presumably are precluded by strong negative feedback stemming from cloud shading (Ramanathan et al., 1989). Thus, a substantial portion of the change should be caused by ice growth. If so, the failure of the benthic foraminifers to record such a change is puzzling. Either not much ice growth has taken place (weakening the argument about strong negative cloud feedback) or the ice growth was accompanied by a warming of bottom waters at this depth $(2200 \mathrm{~m})$ during this transition period (perhaps from an expansion of deep intermediate waters). Event $\mathrm{C}$, denoting a distinct change of planktonic $\delta^{18} \mathrm{O}$ toward lighter values, likewise is not recorded in the benthic foraminifers. Again, a change in ice mass, combined with a compensating change in deep-water temperature, may be involved. The event is at $111 \mathrm{mbsf}$ (4.19 Ma in our age model).

The time between Events $\mathrm{C}$ and B (4.2-3.4 Ma) denotes a climatic optimum (a Pliocene altithermal) in the interval studied. Events B and $A$ are steps leading into a colder climate with increased amounts of ice. After Event A the scatter in the data increases greatly, reflecting the increasing amplitude of glacial-interglacial sea-level variation that results from a buildup of climate-sensitive ice caps (most likely in the Northern Hemisphere, as seen in glacial-derived sediments; Berggren, 1972; Backman, 1979; Shackleton et al., 1984).

The carbon isotope values of the four taxa (from top to bottom in Fig. 4B: G. sacculifer, Pulleniatina, $P$. wuellerstorfi, and $O$. umbonatus) are distinct, with $G$. sacculifer having the highest values, as expected for this shallow-dwelling species. P. wuellerstorfi shows values close to equilibrium, whereas $O$. umbonatus is notably depleted in ${ }^{13} \mathrm{C}$. None of the taxa show striking events or strong trends. Both $G$. sacculifer and $P$. wuellerstorfi show a tendency from more positive to more negative values over the interval studied, presumably indicating the input of organic carbon to the dissolved inorganic carbon (DIC) pool of the ocean. The mid-Pliocene altithermal has relatively low $\delta^{13} \mathrm{C}$ values in $G$. sacculifer, suggesting lowered nutrient concentrations in the deep waters. At the same time, the $O$. umbonatus values are relatively high, supporting a hypothesis of lowered productivity. (The assumption is that increased productivity, by supplying organic matter to the seafloor, would tend to lower the $\delta^{13} \mathrm{C}$ values in this species.) Some indication of cyclicity is present in the record of Pulleniatina.

\section{Carbon Isotope Patterns: Differences Between Taxa}

The age-plot of stable isotopes (Fig. 5) clearly shows the contrast in sampling density between the upper and lower portions of the section that is a result of the changing sedimentation rate (Fig. 2). Thus, documentation is better for pre-Event A time than for postEvent A time. In addition, the scatter is distinctly less in pre-Event A time, which means that each point here is more representative for a broader interval. The oxygen isotopes (Fig. 5A) are given for orientation; they are discussed in Whitman and Berger (1992).

The difference between the values of $G$. sacculifer and $P$. wuellerstorfi in the youngest portion of the section agrees well with that seen in the modern oceanographic data, that is, the present composition of dissolved inorganic carbon (Fig. 3). At nearby GEOSECS Station $246\left(0^{\circ} 00^{\prime} \mathrm{S}, 178^{\circ} 59^{\prime} \mathrm{E}\right)$, the value for $\delta^{13} \mathrm{C}$ of $\Sigma \mathrm{CO}_{2}$ at the surface is near $+1.5 \%$ and that at $2200 \mathrm{~m}$ is between $-0.1 \%$ to $-0.2 \%$ (Kroopnick, 1985), for a difference of $1.6 \%$ to $1.7 \%$. Allowing for the anthropogenic effect of lowered $\delta^{13} \mathrm{C}$ in present surface waters, the expected difference is near $2 \%$. The relevant values in the foraminifers (Appendix C) closely reflect this difference. The agreement supports our assumption of near-equilibrium precipitation for 
Table 2. Carbon difference data.

\begin{tabular}{lrrrr}
\hline & Mean & SD & $N$ & $90 \%$ \\
\hline $\begin{array}{l}\text { For entire core: } \\
\text { G. sacculifer-C. wuellerstorfi }\end{array}$ & 1.88 & 0.20 & 98 & \pm 0.03 \\
C. wuellerstorfi-O. umbonatus & 1.10 & 0.22 & 66 & \pm 0.05 \\
G. sacculifer-Pulleniatina & 1.06 & 0.26 & 115 & \pm 0.04 \\
& & & & \\
For subdivided intervals: & & & & \\
C. wuellerstorfi-O. umbonatus & & & & \\
$\quad<48 \mathrm{~m}(<2.2 \mathrm{Ma})$ & 1.03 & 0.23 & 27 & \pm 0.08 \\
$\quad 48-122 \mathrm{~m}(2.2-4.4 \mathrm{Ma})$ & 1.10 & 0.17 & 30 & \pm 0.05 \\
$>122 \mathrm{~m}(>4.4 \mathrm{Ma})$ & 1.34 & 0.17 & 9 & \pm 0.11 \\
G. sacculifer-Pulleniatina & & & & \\
$<38 \mathrm{~m}(<1.8 \mathrm{Ma})$ & 0.75 & 0.23 & 25 & \pm 0.08 \\
$>38 \mathrm{~m}(>1.8 \mathrm{Ma})$ & 1.15 & 0.19 & 90 & \pm 0.03 \\
$38-85 \mathrm{~m}(1.8-3.4 \mathrm{Ma})$ & 1.14 & 0.15 & 29 & \pm 0.05 \\
$85-122 \mathrm{~m}(3.4-4.4 \mathrm{Ma})$ & 1.06 & 0.17 & 23 & \pm 0.06 \\
$122-160 \mathrm{~m}(4.4-5.3 \mathrm{Ma})$ & 1.31 & 0.17 & 24 & \pm 0.06 \\
$>160 \mathrm{~m}(>5.3 \mathrm{Ma})$ & 1.03 & 0.16 & 14 & \pm 0.08 \\
G. sacculifer-C. wuellerstorfi & & & & \\
$<62 \mathrm{~m}(<2.8 \mathrm{Ma})$ & 1.88 & 0.22 & 35 & \pm 0.06 \\
$62-142 \mathrm{~m}(2.8-4.9 \mathrm{Ma})$ & 1.80 & 0.16 & 40 & \pm 0.04 \\
$>142 \mathrm{~m}(4.9 \mathrm{Ma})$ & 2.03 & 0.14 & 23 & \pm 0.05 \\
\hline
\end{tabular}

Notes: All values are given in per mil $(\%) . S D=$ standard deviation and $N=$ number of samples.

both $G$. sacculifer and $P$. wuellerstorfi for these data. Thus, these two species can be used to obtain the difference in $\delta^{13} \mathrm{C}$ between the surface and the bottom at this site, as a function of time.

The carbon isotope values of $P$. wuellerstorfi are heavier than those of $O$. umbonatus. The average difference between the species is $1.10 \%$, with a standard deviation of $0.22 \%$ (Table 2 ) and a total range of variation of $0.5 \%$ on either side of the mean difference. A similar difference between the two species $(1.0 \%$ ) was found by Woodruff et al. (1980) and in subsequent studies (Shackleton and Hall, 1984; Pisias et al., 1985). Vincent et al. (1981) reported values between $0.9 \%$ and $1.1 \%$ for box cores on Ontong Java Plateau (with the higher values for glacial sediments), and a difference of $1.36 \%$ for the eastern equatorial Pacific. The glacial-postglacial contrast in the difference, and in the east-west gradient, suggest that productivity may play a role in setting the difference in $\delta^{13} \mathrm{C}$ between these two benthic species. Both species are considered epifaunal, that is, living in the top $1 \mathrm{~cm}$ of the sediment (Corliss, 1985). However, the differences in the values of $\delta^{13} \mathrm{C}$ for the two species point to differences in habitat, with $P$. wuellerstorfi being truly epifaunal (Altenbach and Sarnthein, 1989) and hence recording the chemistry of the bottom water, and $O$. umbonatus more infaunal, sensing the oxidation of organic carbon and the release of ${ }^{12} \mathrm{C}$ to interstitial waters within the sediment (cf. Belanger et al., 1981).

The difference in $\delta^{13} \mathrm{C}$ values of $G$. sacculifer and Pulleniatina reflects the well-known difference in habitat of these two planktonic taxa, which is also seen in the $\delta^{18} \mathrm{O}$ values. $G$. sacculifer, as mentioned, lives in surface waters; Pulleniatina lives in the uppermost thermocline and records the lower $\delta^{13} \mathrm{C}$ values at the top of the oxygen minimum. The average difference between the two taxa is $1.06 \%$, with a standard deviation of $0.26 \%$ (Table 2), similar to that found by Williams et al. (1977) and Shackleton and Vincent (1978) for samples in the Indian Ocean. Berger et al. (1978) report differences near 1\%o for Box Core ERDC 92, taken nearby, with the value for glacial time being somewhat smaller.

Scatter plots of $\delta^{13} \mathrm{C}$ values between the various taxa reveal that differences have rather large ranges and do not stay constant, on average (Fig. 6). If one considers separately the plots corresponding to post-Event $\mathrm{A}$ and pre-Event $\mathrm{C}$ time, and the extended altithermal (A to $\mathrm{C}$ ), little apparent correlation exists between the $\delta^{13} \mathrm{C}$ values (Fig. 6, different symbols). The correlation, such as it is, emerges mainly as a result of the overall trend from high to low $\delta^{13} \mathrm{C}$ in all taxa. (Note that the solid line in each of the plots is not the regression,
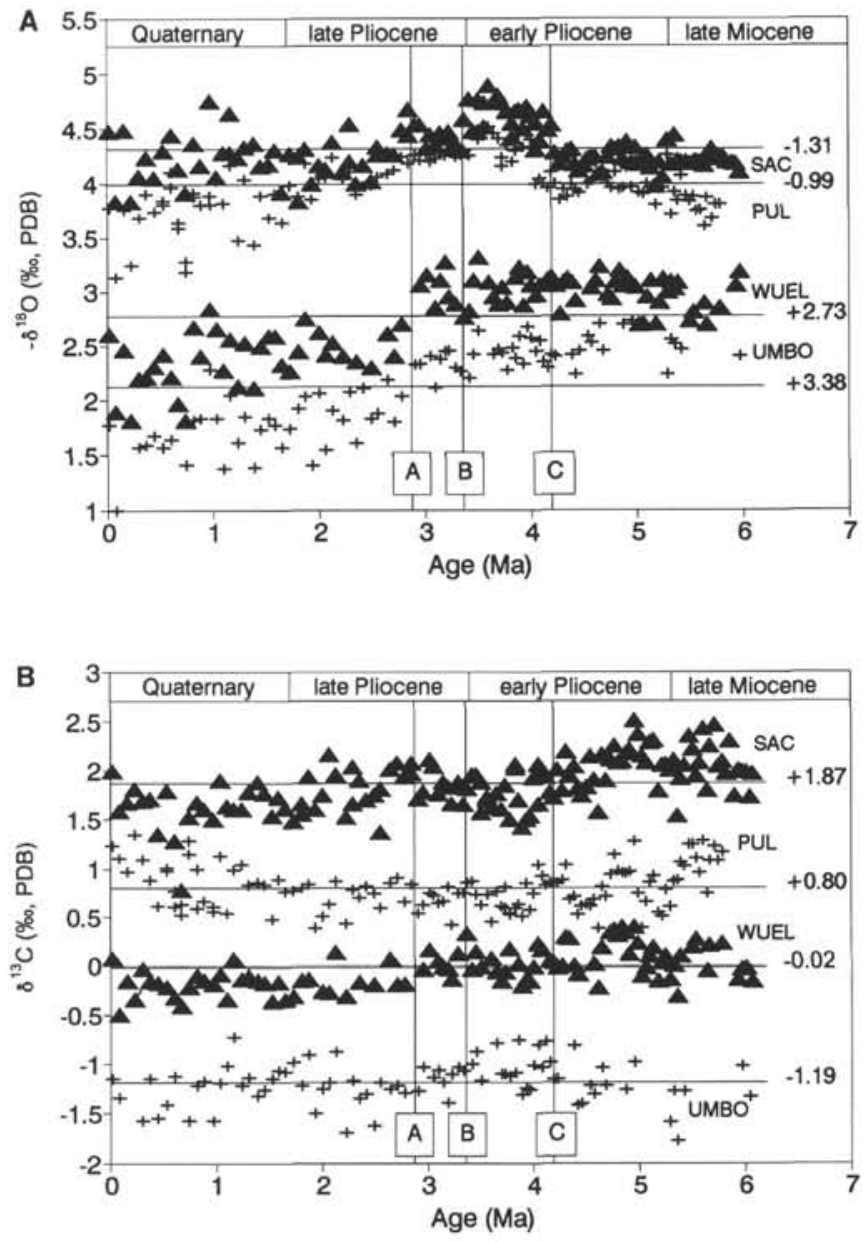

Figure 5. Stable isotope stratigraphy for Site 586; age model as in Figure 2. A. Oxygen isotopes. B. Carbon isotopes. Lines labeled A, B, and C are events seen in the oxygen isotope record (see text). $\mathrm{SAC}=G$. sacculifer, $\mathrm{PUL}=$ Pulleniatina, $\mathrm{WUEL}=P$. wuellerstorfi, and $\mathrm{UMBO}=O$. umbonatus. Average values shown at right are marked by horizontal lines.

but shows the relationship expected for constant offset.) For $G$. sacculifer vs. $P$. wuellerstorfi, the points for Event A to Event C lie distinctly off the main trend: $P$. wuellerstorfi lags much behind $G$. sacculifer in changing to lower $\delta^{13} \mathrm{C}$ values. A single factor (such as the addition of organic matter to the DIC pool) cannot produce such an effect; two or more factors are necessary.

Comparing the range of variability in $\delta^{13} \mathrm{C}$ of $G$. sacculifer and $P$. wuellerstorfi (Fig. 6A), one notes that $G$. sacculifer values typically have a range near $1 \%$, whereas the range of $P$. wuellerstorf $i$ is about one half that. This difference in range indicates that the conditions experienced by $G$. sacculifer in the surface waters are more variable than those seen by $P$. wuellerstorfi at the bottom. A varying global $\delta^{13} \mathrm{C}$ (from external exchange with terrestrial organic carbon, for example) will show in both species, but a varying supply of nutrients (producing changes in vertical fractionation) will in essence only affect $G$. sacculifer. The small reservoir of surface waters readily reflects a change in partitioning between surface waters and deep waters, whereas the deep waters are much less responsive.

Comparing the carbon isotope values for the two benthic species (Fig. 6B), we note that the scatter is rather large. Knowing the value of one of these species provides a poor basis for guessing the value of the other. Thus, the commonly used assumption of constant offset is highly questionable in this instance. A comparison of the two 

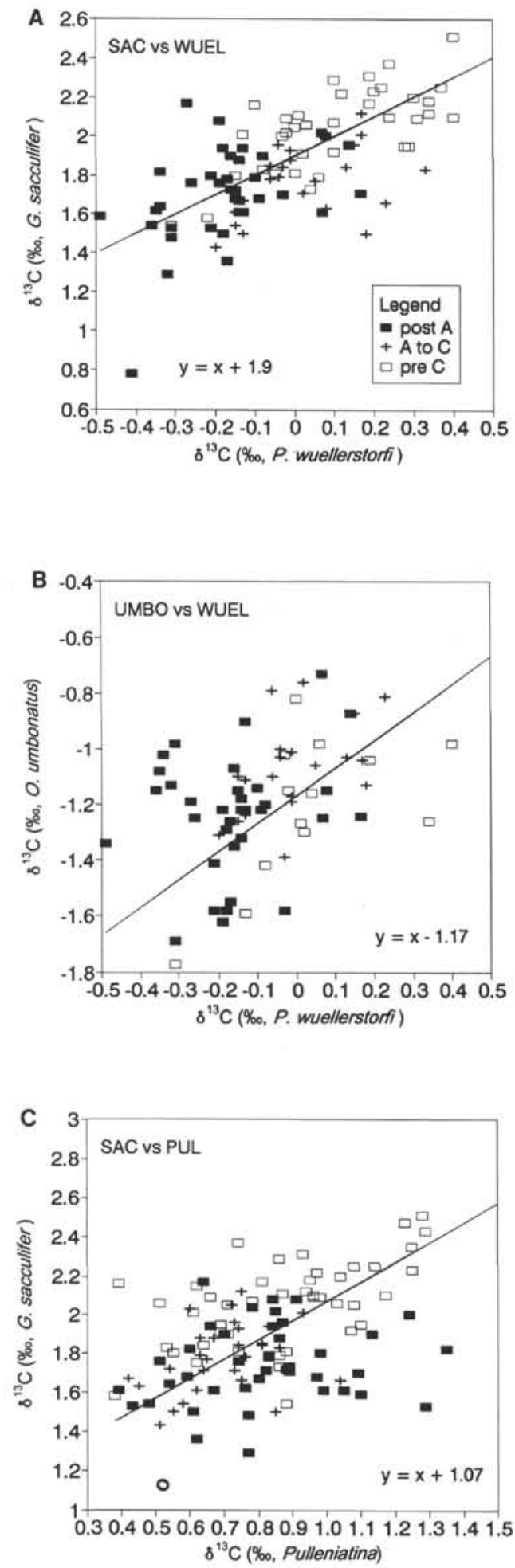

Figure 6. Scatter plots of $\delta^{13} \mathrm{C}$ values of one taxon vs. another. A. G. sacculifer vs. P. wuellerstorfi. B. O. umbonatus vs. P. wuellerstorfi. C. G. sacculifer vs. Pulleniatina. The line denotes constant offset, given by the equation in each panel. Symbols refer to different time spans as defined by Events A, B, and C (as shown in legend).
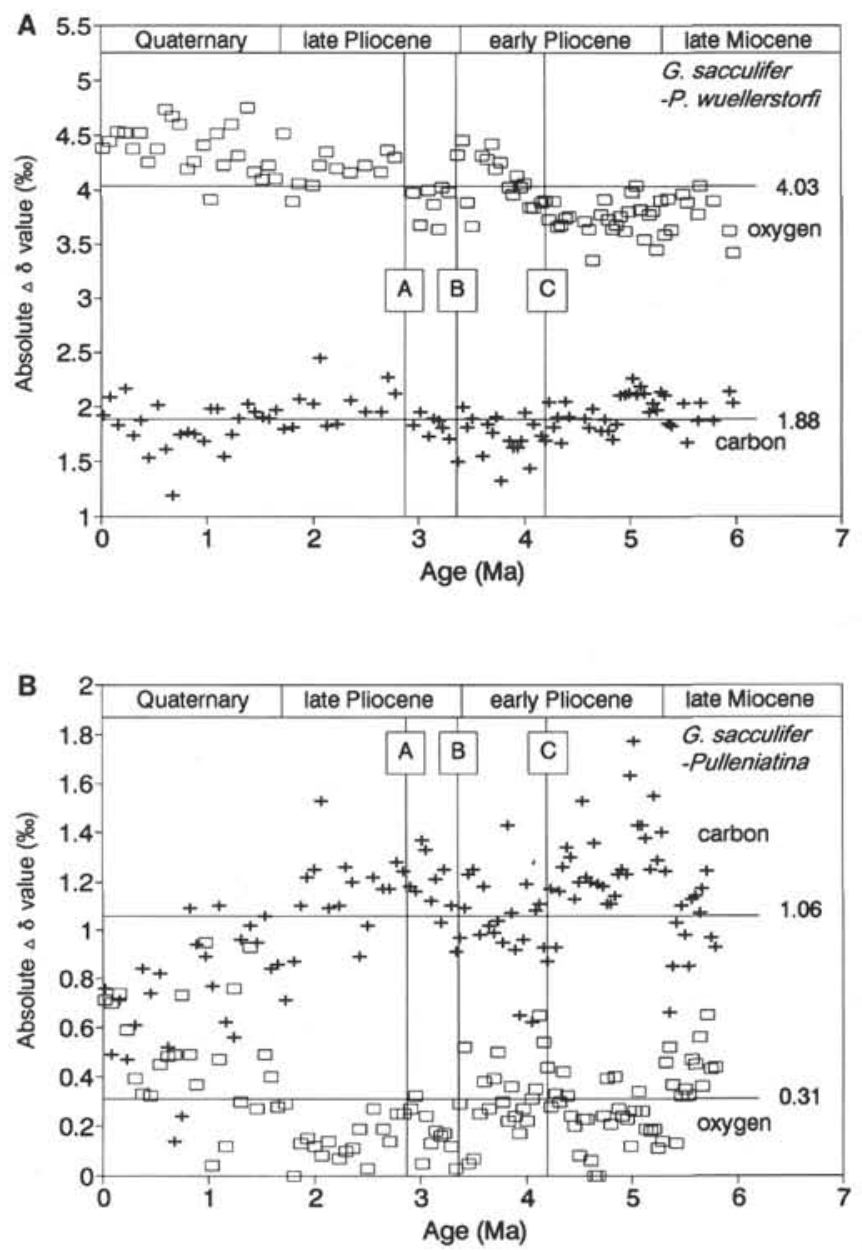

Figure 7. Differences in stable isotope values between $G$. sacculifer and two other taxa. A. G. sacculifer and $P$. wuellerstorfi. B. G. sacculifer and Pulleniatina. Open squares denote $\delta^{18} \mathrm{O}$ and crosses denote $\delta^{13} \mathrm{C}$ values. Average differences shown at right and marked by horizontal lines.

planktonic species (Fig. 6C) shows that correlations change significantly through time: whereas correspondence is good in pre-Event $\mathrm{C}$ time, it is very poor in post-Event A time. Again, G. sacculifer shows a large range, the comparison species a smaller one.

\section{Carbon Isotope Patterns: Difference Trends}

Differences in stable isotope records are further explored in Figure 7, where we compare $\delta^{18} \mathrm{O}$ and $\delta^{13} \mathrm{C}$ contrasts between taxa in the time domain. Post-Event A time is characterized by increasing and greater-than-average differences in $\delta^{18} \mathrm{O}$ values between $G$. sacculifer and $P$. wuellerstorfi, and an overall decrease in $\delta^{13} \mathrm{C}$ difference (Fig. 7A). A tendency for negative correlation between the differences persists throughout the section, indicating that whenever the thermal gradient increases (increased difference in $\delta^{18} \mathrm{O}$ ), there is an increased likelihood for a lowered nutrient content in deep waters (decreased contrast in $\delta^{13} \mathrm{C}$ ). This same relationship is reflected in the difference stratigraphy of G. sacculifer and Pulleniatina (Fig. 7B): increased temperature contrast (i.e., shallowing of the thermocline) parallels decreased $\delta^{13} \mathrm{C}$ contrast (i.e., nutrient content of the thermocline). The trend in the Quaternary is especially remarkable in this respect; $\delta^{18} \mathrm{O}$ differences increase greatly over the general average of $0.31 \%$, whereas $\delta^{13} \mathrm{C}$ differences drop way below their average of $1.06 \%$. 
On the whole, the patterns suggest that as the deep ocean becomes colder and the thermocline rises, vertical fractionation becomes less effective, that is, nutrient concentrations decrease.

\section{Carbon Isotope Patterns: Variability Through Time}

The variability of stable isotopes changes through time and reaches a maximum in post-Event $\mathrm{A}$ time in almost all categories (excepting $\delta^{13} \mathrm{C}$ of $P$. wuellerstorfi) (Fig. 8). Variability is taken as the standard deviation about the mean of five consecutive values down the hole, that is, an interval of $8 \mathrm{~m}$ (ca. 200-400 k.y., depending on the sedimentation rate). Among the $\delta^{18} \mathrm{O}$ records (Fig. $8 \mathrm{~A}$ ), the one of $G$. sacculifer is the least variable, supporting the notion that surface temperatures tend to stay constant in this region because of the strong negative cloud feedback. (Seasonal changes are on the order of $1^{\circ} \mathrm{C}$.) Also, a general cooling (which would be reflected in ice buildup and a lowering of deep-water temperatures) could conceivably increase the delivery of warm surface waters to the western equatorial Pacific by strengthened trade winds. Thus, the effects of ice buildup would be compensated in part. Variability in the $\delta^{18} \mathrm{O}$ record of Pulleniatina is somewhat greater, especially in the Quaternary, and the same is true for the benthic species. The range of these fluctuations is readily accommodated by an ice effect on the order of $1 \%$. The lesser variability in pre-Event A time, presumably, indicates that the effect from the waxing and waning of continental ice on $\delta^{18} \mathrm{O}$ values of the ocean was less important before $3 \mathrm{Ma}$ than afterward. Variations in depth-to-thermocline, and in proportion of North Atlantic Deep Water (NADW) component in the waters bathing the site of deposition, also have to be considered when discussing these records.

The corresponding $\delta^{13} \mathrm{C}$ records show much less change in variability through time, compared with the $\delta^{18} \mathrm{O}$ records (Fig. $8 \mathrm{~B}$ ). In the carbon isotope record $G$. sacculifer is the most variable, and $P$. wuellerstorfi the least, as mentioned, reflecting the inertia of deep-water carbon isotopic composition. There is some indication that variability is at a minimum in the extended Pliocene altithermal (Events A to C) in all taxa. If so, variability in the carbon isotope record is a function of the extent of cooling, that is, ice mass extant. However, no strong increase is present in overall variability (or in the variation of variability) toward the late Quaternary, as seen in the oxygen isotopes.

\section{Productivity-related Indices}

The $\delta^{13} \mathrm{C}$ records of the different taxa are closely tied to productivity changes in the ocean. To avoid circular reasoning, it is important to attempt to reconstruct such changes in ways other than through the carbon isotope record itself. One well-established proxy for productivity is the abundance of benthic foraminifers in the sediment, which records the supply of organic matter to the seafloor (Altenbach and Sarnthein, 1989; Herguera and Berger, 1991). Overall trends in this index show a general increase of both abundance and variability in abundance through the period studied (Fig. 9A). Numbers of benthic foraminifers $>250 \mu \mathrm{m}$ per gram typically show values between 10 and 15 in the early Pliocene, increasing to between 15 and 30 in the Quaternary. This trend actually represents a decrease (or at best no change) in the accumulation rate of benthic foraminifers, as the sedimentation rate differs by a factor of 2 for these time periods. Thus, a slight reduction in overall productivity seems indicated. There is some hint of cyclicity on a 1-m.y. scale (Fig. 9A, running average).

Somewhat surprisingly, the relative abundance of Uvigerina, on the whole, increases over the period studied, except for some unusually high values in the latest Miocene (Fig. 9B). A high abundance of $U$ vigerina has been associated with low oxygen content of bottom waters and with a high supply of organic matter (Streeter and Shackleton, 1979; Douglas and Woodruff, 1981; Corliss, 1982; Corliss et al., 1986; Lutze et al., 1986; Zahn et al., 1986). In the case at hand, lowered oxygen content would seem to be the preferred
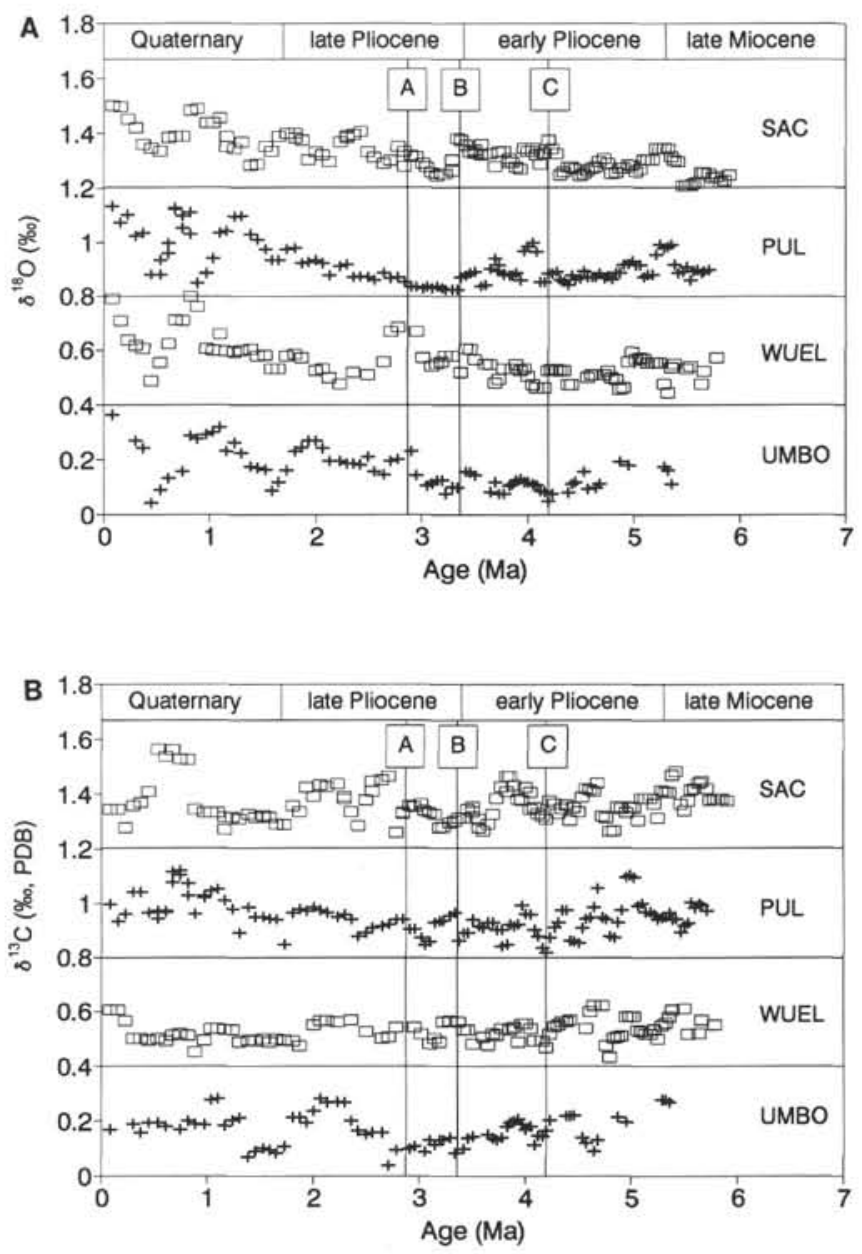

Figure 8. Variability of stable isotopes as a function of age. Variability is given as the standard deviation from the mean of 5 consecutive values downhole (ca. 8-m interval). A. Oxygen isotopes. B. Carbon isotopes. $\mathrm{SAC}=\mathrm{G}$. sacculifer, $\mathrm{PUL}=$ Pulleniatina, $\mathrm{WUEL}=P$. wuellerstorfi, and $\mathrm{UMBO}=O$. umbonatus. In each panel, the horizontal line is zero (offset in steps of $0.4 \%$ added to raw standard deviation $[\mathrm{SD}]$ values, for separation).

explanation, considering the lack of evidence for increased productivity. However, temporarily increased output from pulsed productivity, even if occurring on the background of reduced production, may have to be considered in the context as an important factor in the Uvigerina pattern.

A general decrease in oxygen in the latest Neogene at this site-or pulsed reduction of oxygen-is not supported by the carbon isotope data, which do not show increased differences between $G$. sacculifer and $P$. wuellerstorfi parallel to the increase in relative abundance of Uvigerina (cf. Figs. 7A and 9B). However, a decrease of oxygen in Pacific deep waters is expected from the turning up of deep-water production in the North Atlantic in the late Pliocene, a point taken up in the discussion section.

It seems unlikely that upwelling, on the whole, should have decreased in the late Pliocene and since. The increase in the depth gradient in shallow-water temperature (as seen in the oxygen isotope data of the two planktonic species; Fig. 7B) suggests that the thermocline rose (rather than being depressed by warm-water pileup). Also, general considerations involving the strength of trade winds (Arrhenius, 1952; Leinen and Heath, 1981) would seem to favor increased rather than decreased upwelling. A trend of decreasing productivity combined with a trend of increased upwelling would imply the depletion of nutrients from thermocline waters (Berger and 

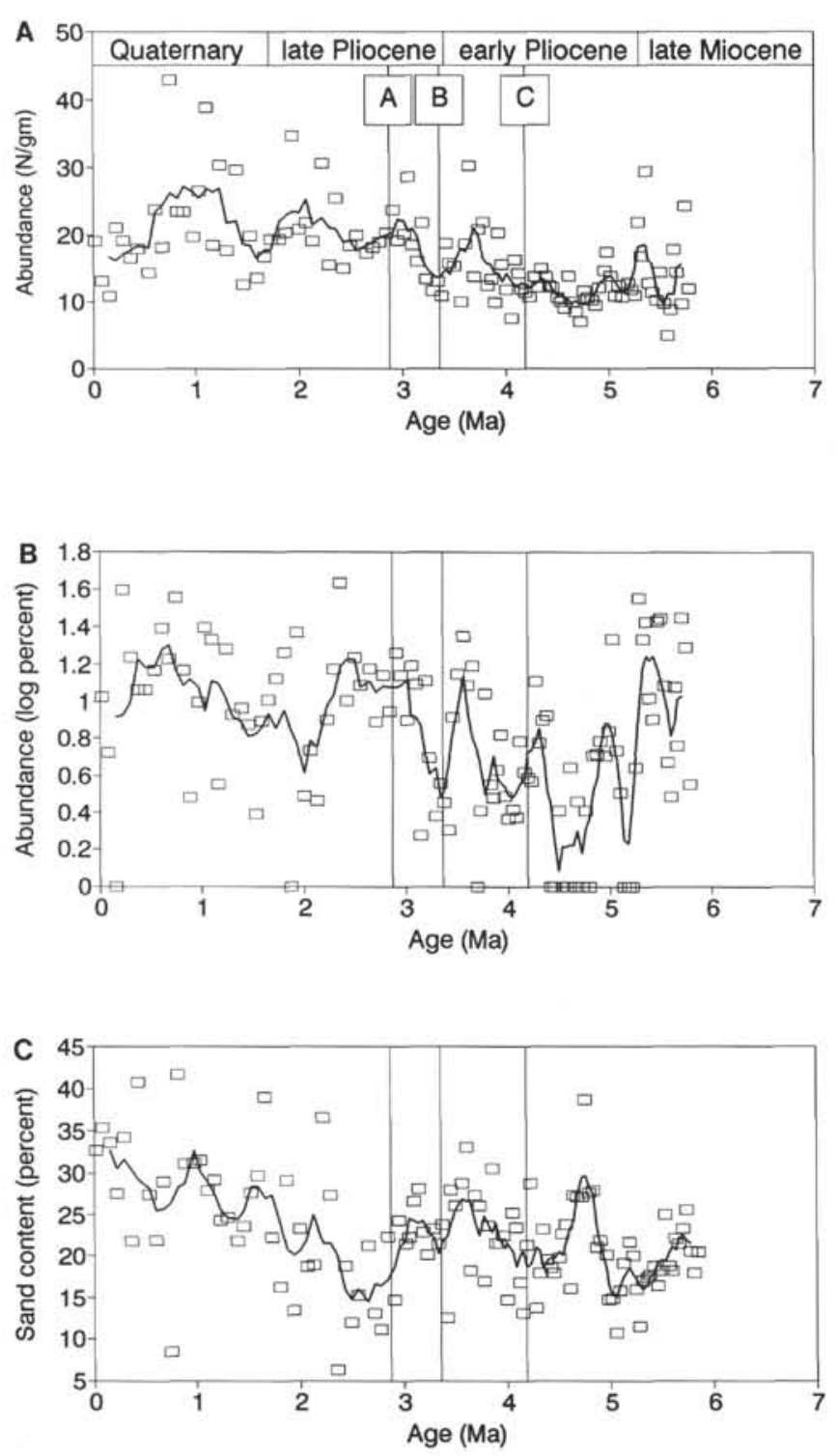

Figure 9. Productivity-related sediment properties, Site 586. A. Benthic foraminifers per gram of sediment in the fraction $>250 \mu \mathrm{m}$. B. Log of percent abundance of Uvigerina spp. C. Sand content. The solid lines through the data points are 5-point sliding averages. Events labeled A, B, and C as in Figure 5.

Wefer, 1991; Berger and Herguera, 1992). It remains to be demonstrated, however, that physical upwelling, in fact, proceeded while nutrients declined. The problem is that the reconstruction of upwelling almost invariably involves productivity-related proxies.

Sand content reflects, in essence, the ratio between foraminifers and coccoliths, which may be taken as an index of productivity when winnowing and dissolution are unimportant (Berger, 1976). The sand fraction shows an overall increase after $3 \mathrm{Ma}$ in the section studied (Fig. 9C). The scatter also greatly increases after $3 \mathrm{Ma}$. However, the accumulation of sand does not increase, as the change in sedimentation rate more than compensates for the change in sand content. Overall, then, no increase occurs in the supply of foraminifers. It is likely that the variations in sand content are largely produced by winnowing, as has been proposed for the late Quaternary in this region (Wu and Berger, 1991). A more detailed age model than the one here used will be necessary to show this for fluctuations on the scale of $1 \mathrm{~m} . \mathrm{y}$. and less. An overall increase in winnowing could be the result, for example, of increased tidal action at depth, as shelves are no longer available for tidal energy destruction after large-scale regression. Other possibilities also must be considered (e.g., trends in tsunami activity and frequency of benthic storms).

\section{DISCUSSION AND SUMMARY \\ Major Trends}

The main feature of our oxygen isotope record is Event A, the central cooling step that occurs between 2.8 and $2.9 \mathrm{~m}$.y. ago in our age model. Event A is close enough to the timing of the establishment of the Panama Isthmus (Keigwin, 1978, 1982) to suggest some sort of causal connection by means of changes in the energy budget (Maier-Reimer et al., 1990). What is surprising is that the carbon isotope record does not clearly reflect this change, although much evidence exists that a profound change takes place in the way the climatic system works at that time (expressed as a change in cyclicities and covariance patterns of $\delta^{18} \mathrm{O}$; see Tiedemann, 1991; Prell, 1984).

Compared with the oxygen isotope record, the carbon isotope record is both more complicated and less eventful (Fig. 10). No major steps occur that would point to drastic changes in the carbon composition of the global ocean, either permanently or temporarily. Instead, we see quasi-cyclic variations, presumably reflecting the up and down of sea level, and the accompanying exchange of the ocean's carbon reservoir with shallow marine and terrestrial reservoirs. However, distinct trends are present that reflect the overall climatic change from a world with only a southern ice cap to one with permanent ice masses at both poles and with greatly fluctuating volumes in the north. These trends include an overall decrease in oceanic $\delta^{13} \mathrm{C}$, an apparent decrease in productivity, and an apparent change in deep-water properties, toward greater asymmetry between the Atlantic and Pacific oceans. In the following material, we discuss these trends and offer additional evidence bearing on their existence and magnitude.

The trend of a gradual decrease in $\delta^{13} \mathrm{C}$ values since the early Pliocene, in both benthic and planktonic records, indicates a change in the composition of the global carbon reservoir. We suggest that global regression is responsible, increasing the delivery of light carbon from shallow marine or terrestrial organic matter to the oceans. The general trend of a falling sea level over this time period supports this hypothesis. The curve presented by Haq et al. (1987) shows a drastic and permanent fall of average sea level shortly after $3 \mathrm{Ma}$. Increased erosion of soil carbon is compatible with the change in the ratio of ${ }^{87} \mathrm{Sr} /{ }^{86} \mathrm{Sr}$ in seawater, as preserved in carbonate sediments (Koepnick et al., 1988). Since the early Pliocene, the heavier isotope has increased, in response to increased delivery from terrestrial sources because the exposure of a greater area of continental rocks to weathering results in an increased flux of radiogenic ${ }^{87} \mathrm{Sr}$ to the oceans (Palmer and Elderfield, 1985; Capo and DePaolo, 1990).

One could argue, from the decreasing difference in $\delta^{13} \mathrm{C}$ values of $G$. sacculifer and $P$. wuellerstorfi within the last 3 m.y. (Fig. 7A) that an overall decrease in productivity in this time interval occurred at this site. A lowering of accumulation rates is in accord with this observation (Fig. 2). However, a substantial portion of the reduction in the sedimentation rate through the period considered presumably is caused by increased winnowing rather than by a drop in productivity. The sand fraction changes from a background value near $20 \%$ to about 35\% in the latest Quaternary (Fig. 9C). If this difference were entirely a result of winnowing, the loss of sediment (made up of silt and clay) is given by

$$
L=1-S_{o} / S,
$$

where $S_{o}$ is the initial sand content, and $S$ the final one after winnowing. Thus, about $43 \%$ of the sediment is missing under this assumption, for a reduction of the sedimentation rate to $57 \%$ of the original value.

The actual reduction of the sedimentation rate is close to a factor of 2 , that is, $50 \%$ of the original material is lost by winnowing, under the 

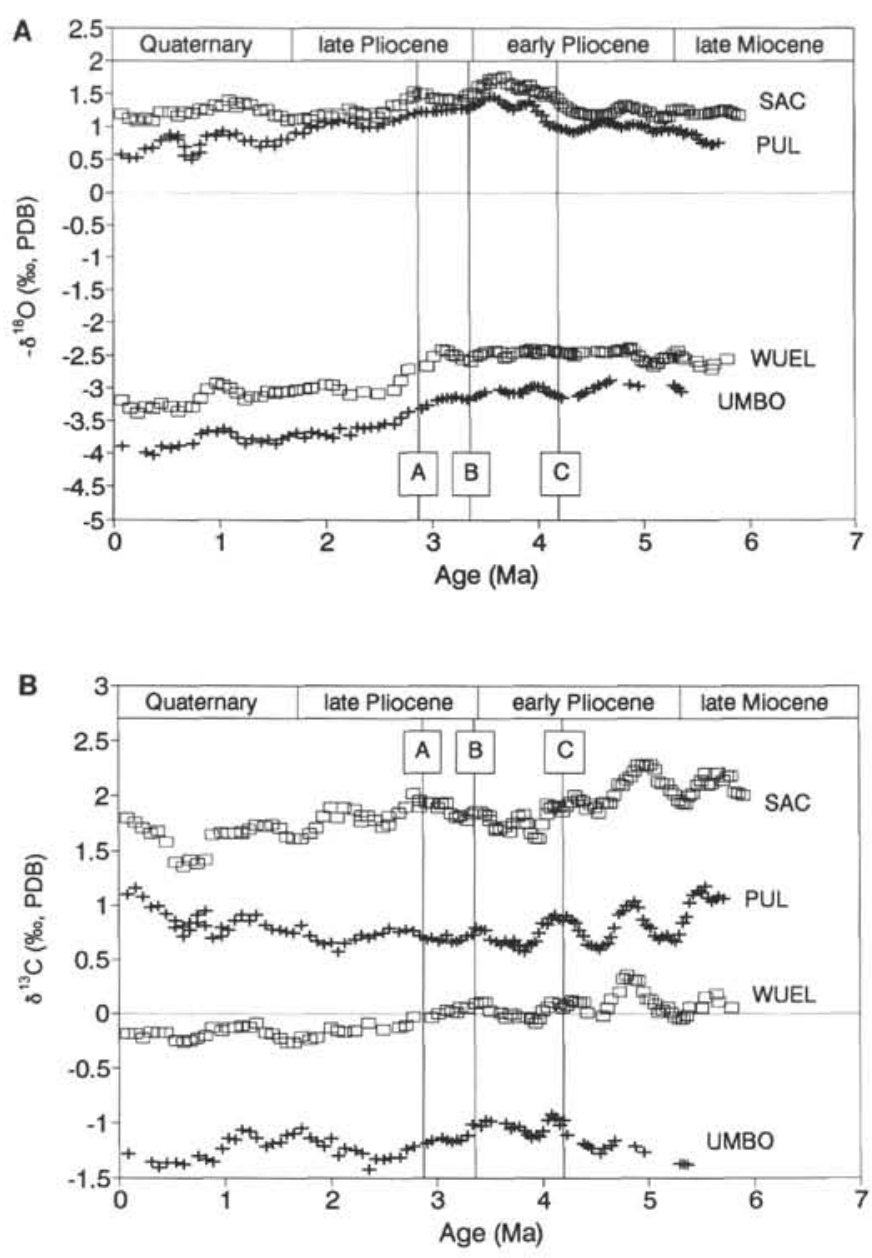

Figure 10. Long-term trends in stable isotope compositions of four foraminiferal taxa: G. sacculifer (SAC), Pulleniatina (PUL), P. wuellerstorfi (WUEL), and $O$. umbonatus (UMBO). A. Oxygen isotopes. B. Carbon isotopes. Data smoothed using 5-point sliding averages.

assumption that winnowing produces the changes in rate. If we use the sand fraction $>147 \mu \mathrm{m}$ in the data of Gardner et al. (1986) to make the same loss calculation again, we do obtain an apparent reduction approaching $50 \%$. Thus, a substantial portion of the decrease in accumulation rate in the late Neogene, at this site, could easily be a result of the downslope removal of fine material, including a portion of the fine sand. If this process of downslope removal was widespread during the Pleistocene, it would have constantly delivered carbonate to the deepest waters, increasing the alkalinity there, and lowering the carbonate compensation depth (CCD). The effect would be a reduction in $\mathrm{pCO}_{2}$ in the atmosphere. A drop of the CCD on the order of $500 \mathrm{~m}$ (Peterson and Backman, 1990) would have produced a reduction in $\mathrm{pCO}_{2}$ of about $30 \mathrm{ppm}$, other factors being equal (Berger and Spitzy, 1988). The grain-size patterns, then, caution us not to interpret the changes in accumulation rate as being mainly caused by changes in productivity, and the hypothesis of alkalinity increase from winnowing gives us a mechanism to decrease atmospheric $\mathrm{CO}_{2}$ independently of the efficacy of the biological pump.

\section{Thermocline Depletion}

Thermocline depletion is indicated especially for the Pleistocene by the convergence in the carbon values of the two planktonic species (Fig. 10B). The trend implies that the increased supply of upwelling cold water (as indicated by divergence in $\delta^{18} \mathrm{O}$ values; Fig. 10A) does not bring an increased supply of nutrients to fuel the productivity of surface waters. Conceivably, increased productivity in the source areas of the thermocline water (subantarctic, subarctic, or both) removes nutrients there, resulting in decreased supply to intermediate waters, and hence to tropical upwelling regions. This mechanism may be important on a glacial-interglacial scale as well (Keir, 1988). Alternatively, or in addition, nutrients are extracted in the margins as the planet cools, leaving less for the open ocean. Such an explanation would be in accord with decreased silica accumulation during glacial periods, in this region (Lange and Berger, this volume).

One possible explanation for nutrient depletion of thermocline waters in their areas of origin is an increase in the supply of iron during the last 6 m.y. (Berger and Wefer, 1991). Iron may be limiting to productivity in high latitudes, and increased glacial productivity there in consequence of a greater dust supply has been postulated (Martin, 1990). Boyle and Keigwin (1987) assumed decreased intermediatewater nutrient content in the North Atlantic during the last glacial and explained the effect with reduced NADW production and increased North Atlantic intermediate water production. A more general model, postulating transfer of nutrients to deep waters, is given by Boyle (1988a, 1988b). The glacial depletion of nutrients apparently occurred in North Pacific intermediate waters down to a depth of $2000 \mathrm{~m}$, judging from radiocarbon evidence and stable isotope data (Berger, 1987; Duplessy et al., 1988; Herguera et al., 1991, 1992). Similar data are reported from the Indian Ocean (Kallel et al., 1988). Thus, thermocline depletion during glacial phases is a global phenomenon. We assume that the Pleistocene as a whole represents glacial conditions, compared with the Pliocene.

\section{Comparison with Atlantic Record}

The crude analogy setting the Pleistocene equal to glacial conditions and the Pliocene equal to interglacial ones is useful, but it has to be applied with discretion. For example, it is now generally accepted that the production of NADW was reduced during glacials, compared with interglacials, so that the asymmetry in $\delta^{13} \mathrm{C}$ values between the Atlantic and Pacific oceans was reduced during cold periods (e.g., Shackleton et al., 1983b). Yet, when comparing the deep-ocean record from Site 586 with that from Site 552 in the North Atlantic (Fig. 11), we note that the asymmetry in the $\delta^{13} \mathrm{C}$ is strong throughout the period. If anything, it has increased slightly during the last 3 m.y.

In this case, then, the apparent change in the effects of NADW production is not exactly analogous to the NADW fluctuations within the Pleistocene, when NADW is turned down during the glacials (Duplessy et al., 1980; Boyle and Keigwin, 1982; Curry et al., 1988). This situation indicates that contrasts within the Pleistocene cannot be readily extrapolated to warm/cold contrasts comprising larger time scales.

\section{ACKNOWLEDGMENTS}

We are indebted to Edith Vincent, Robin Keir, and Frances Parker for advice during the initial stages of the work here reported on. Christina Ravelo read an earlier draft of the manuscript and made many useful suggestions for improvement. Supported by the U.S. National Science Foundation (Grants OCE88-16167 and OCE90-17717).

\section{REFERENCES*}

Altenbach, A.V., and Sarnthein, M., 1989. Productivity record in benthic foraminifera. In Berger, W.H., Smetacek, V.S., and Wefer, G. (Eds.), Productivity of the Ocean: Present and Past: Chichester (Wiley), 255-269.

\footnotetext{
* Abbreviations for names of organizations and publication titles in ODP reference lists follow the style given in Chemical Abstracts Service Source Index (published by American Chemical Society).
} 
Andrews, J.E., Packham, G., et al., 1975. Init. Repts. DSDP, 30: Washington (U.S. Govt. Printing Office).

Arrhenius, G., 1952. Sediment cores from the East Pacific. Swed. Deep-Sea Exped., 1947-1948, 5 (Pts. 1-3).

Backman, J., 1979. Pliocene biostratigraphy of DSDP Sites 111 and 116 from the North Atlantic Ocean and the age of Northern hemisphere glaciation. J. Stockh. Contrib. Geol., 32:115-137.

Barton, C.E., and Bloemendal, J., 1986. Paleomagnetism of sediments collected during Leg 90, Southwest Pacific. In Kennett, J.P., von der Borch, C.C., et al., Init. Repts. DSDP, 90, Pt. 2: Washington (U.S. Govt. Printing Office), 1273-1316.

Belanger, P.E., Curry, W.B., and Matthews, R.K., 1981. Core-top evaluation of benthic foraminiferal isotopic ratios for paleo-oceanographic interpretations. Palaeogeogr., Palaeoclimatol., Palaeoecol., 33:205-220.

Berger, W.H., 1976. Biogenous deep-sea sediments: production, preservation and interpretation. In Riley, J.P., and Chester, R. (Eds.), Treatise on Chemical Oceanography (Vol. 5): London (Academic Press), 265-388.

, 1987. Ocean ventilation during the last 12,000 years: hypothesis of counterpoint deep water production. Mar. Geol., 78:1-10.

Berger, W.H., Bonneau, M.-C., and Parker, F.L., 1982. Foraminifera on the deep-sea floor: lysocline and dissolution rate. Oceanol. Acta, 5:249-258.

Berger, W.H., and Herguera, J.C., 1992. Reading the sedimentary record of the ocean's productivity. In Falkowski, P.G., and Woodhead, A.D. (Eds.), Primary Productivity and Biogeochemical Cycles in the Sea: New York (Plenum), 455-486.

Berger, W.H., and Johnson, T.C., 1976. Deep-sea carbonates: dissolution and mass wasting on Ontong-Java Plateau. Science, 192:785-787.

Berger, W.H., and Keir, R.S., 1984. Glacial-Holocene changes in atmospheric $\mathrm{CO}_{2}$ and the deep-sea record. In Hansen, J.E., and Takahashi, T. (Eds.), Climate Processes and Climate Sensitivity (Vol. 5). Am. Geophys. Union, Maurice Ewing Ser., 29:337-351.

Berger, W.H., and Killingley, J.S., 1982. Box cores from the Equatorial Pacific: ${ }^{44} \mathrm{C}$ sedimentation rates and benthic mixing. Mar. Geol., 45:93-125.

Berger, W.H., Killingley, J.S., and Vincent, E., 1978. Stable isotopes in deep-sea carbonates: Box Core ERDC-92, west-equatorial Pacific. Oceanol. Acta, 1:203-216.

Berger, W.H., Killingley, J.S., and Vincent, E., 1987. Time scale of Wisconsin/Holocene transition: oxygen isotope record in the western equatorial Pacific. Quat. Res., 28:295-306.

Berger, W.H., and Spitzy, A., 1988. History of atmospheric $\mathrm{CO}_{2}$ : constraints from the deep-sea record. Paleoceanography, 3:401-411.

Berger, W.H., and Vincent, E., 1986. Deep-sea carbonates: reading the carbon isotope signal. Geol. Rundsch., 75:249-269.

Berger, W.H., and Wefer, G., 1991. Productivity of the glacial ocean: discussion of the iron hypothesis. Limnol. Oceanogr., 36:1899-1918.

Berggren, W.A., 1972. Late Pliocene-Pleistocene glaciation. In Laughton, A.S., Berggren, W.A., et al., Init. Repts. DSDP, 12: Washington (U.S. Govt. Printing Office), 953-963.

Berggren, W.A., Kent, D.V., and Van Couvering, J.A., 1985. The Neogene: Part 2. Neogene geochronology and chronostratigraphy. In Snelling, N.J. (Ed.), The Chronology of the Geological Record. Geol. Soc. London Mem., 10:211-260.

Boyle, E.A., 1988a. Vertical oceanic nutrient fractionation and glacial/interglacial $\mathrm{CO}_{2}$ cycles. Nature, 331:55-56.

1988b. The role of vertical chemical fractionation in controlling late Quaternary atmospheric carbon dioxide. J. Geophys. Res., 93:1570115714.

Boyle, E.A., and Keigwin, L.D., 1982. Deep circulation of the North Atlantic over the last 200,000 years: geochemical evidence. Science, 218:784-787.

, 1987. North Atlantic thermohaline circulation during the past 20,000 years linked to high-latitude surface temperature. Nature, 330:35-40.

Broecker, W.S., 1973. Factors controlling $\mathrm{CO}_{2}$ content in the oceans and atmosphere. In Woodwell, G.M., and Pecan, E.V. (Eds.), Carbon and the Biosphere. AEC Symp., 30:32-50.

1982. Ocean chemistry during glacial time. Geochim. Cosmochim. Acta, 46:1689-1705.

Capo, R.C., and DePaolo, D.J., 1990. Seawater strontium isotopic variations from 2.5 million years ago to the present. Science, 249:51-55.

Corliss, B.H., 1982. Linkage of North Atlantic and Southern Ocean deep-water circulation during glacial intervals. Nature, 298:458-460.

, 1985. Microhabitats of benthic foraminifera within deep-sea sediments. Nature, 314:435-438.

Corliss, B.H., Martinson, D.G., and Keefer, T., 1986. Late Quaternary deepocean circulation. Geol. Soc. Am. Bull., 97:1106-1121.
Curry, W.B., Duplessy, J.-C., Labeyrie, L.D., and Shackleton, N.J., 1988. Changes in the distribution of $\delta^{13} \mathrm{C}$ of deep water $\mathrm{\Sigma CO}_{2}$ between the last glaciation and the Holocene. Paleoceanography, 3:317-341.

Curry, W.B., and Miller, K.G., 1990. Oxygen and carbon isotopic variation in Pliocene benthic foraminifers of the equatorial Atlantic. In Ruddiman, W., Sarnthein, M., et al., Proc. ODP, Sci. Results, 108: College Station, TX (Ocean Drilling Program), 157-166.

Dietrich, G., Kalle, K., Krauss, W., and Siedler, G., 1980. General Oceanography: An Introduction (2nd ed.): New York (Wiley-Interscience).

Douglas, R.G., and Woodruff, F., 1981. Deep sea benthic foraminifera. In Emiliani, C. (Ed.), The Sea (Vol. 7): The Oceanic Lithosphere: New York (Wiley-Interscience).

Dunbar, R.B., and Wefer, G., 1984. Stable isotopic fractionation in benthic foraminifera from the Peruvian continental margin. Mar. Geol., 59:215-225.

Duplessy, J.-C., Moyes, J., and Pujol, C., 1980. Deep water formation in the North Atlantic Ocean during the last ice age. Nature, 286:479-482.

Duplessy, J.C., Shackleton, N.J., Fairbanks, R.G., Labeyrie, L., Oppo, D., Kallel, N., 1988. Deep-water source variations during the last climatic cycle and their impact on the global deep-water circulation. Paleoceanography, 3:343-360.

Fischer, A.G., and Arthur, M.A., 1977. Secular variations in the pelagic realm. Spec. Publ.-Soc. Econ. Paleontol. Mineral., 25:19-50.

Gardner, J.V., Dean, W.E., Bisagno, L., and Hemphill, E., 1986. Late Neogene and Quaternary coarse-fraction and carbonate stratigraphies for Site 586 on Ontong-Java Plateau and Site 591 on Lord Howe Rise. In Kennett, J.P., von der Borch, C.C., et al., Init. Repts. DSDP, 90: Washington (U.S. Govt. Printing Office), 1201-1224.

Graham, D.W., Corliss, B.H., Bender, M.L. and Keigwin, L.D., 1981. Carbon and oxygen isotopic disequilibria of recent deep-sea benthic foraminifera. Mar. Micropaleontol., 6:483-497.

Grossman, E.L., 1987. Stable isotopes in modern benthic foraminifera: a study of vital effect. J. Foraminiferal Res., 17:48-61.

Haq, B.U., Hardenbol, J., and Vail, P.R., 1987. Chronology of fluctuating sea levels since the Triassic. Science, 235:1156-1167.

Hebbeln, D., Wefer, G., and Berger, W.H., 1990. Pleistocene dissolution fluctuations from apparent depth of deposition in Core ERDC-127P, westequatorial Pacific. Mar. Geol., 92:165-176.

Herguera, J.C., and Berger, W.H., 1991. Paleoproductivity from benthic foraminifera abundance: glacial to postglacial change in the west-equatorial Pacific. Geology, 19:1173-1176.

Herguera, J.C., Jansen, E., and Berger, W.H., 1992. Evidence for a bathyal front at 2000-m depth in the glacial Pacific, based on a depth transect on Ontong Java Plateau. Paleoceanography, 7:273-288.

Herguera, J.C., Stott, L.D., and Berger, W.H., 1991. Glacial deep-water properties in the west-equatorial Pacific: bathyal thermocline near a depth of $2000 \mathrm{~m}$. Mar. Geol., 100:201-206.

Jansen, E., Sjøholm, J., Bleil, U., and Erichsen, J.A., 1990. Neogene and Pleistocene glaciations in the Northern Hemisphere and late Miocene-Pliocene global ice volume fluctuations: evidence from the Norwegian Sea. In Bleil, U., and Thiede, J. (Eds.), Geological History of the Polar Oceans: Arctic Versus Antarctic: Dordrecht (Kluwer Academic), 677-705.

Johnson, T.C., Hamilton, E.L., and Berger, W.H., 1977. Physical properties of calcareous ooze: control by dissolution at depth. Mar. Geol., 24:259-277.

Kallel, N., Labeyrie, L.D., Juillet-Leclerc, A., and Duplessy, J.-C., 1988. A deep hydrological front between intermediate and deep-water masses in the glacial Indian Ocean. Nature, 333:651-655.

Keigwin, L.D., 1978. Pliocene closing of the Isthmus of Panama, based on biostratigraphic evidence from nearby Pacific Ocean and Caribbean Sea cores. Geology, 6:630-634.

-1982. Isotopic paleoceanography of the Caribbean and east Pacific: role of Panama uplift in the late Neogene time. Science, 217:350-353.

, 1984. Stable isotopic results on upper Miocene and lower Pliocene foraminifers from Hole 552A. In Roberts, D.G., Schnitker, D., et al., Init. Repts. DSDP, 81: Washington (U.S. Govt. Printing Office), 595-597.

1986. Pliocene stable-isotope record of Deep Sea Drilling Project Site 606: sequential events of ${ }^{18} \mathrm{O}$ enrichment beginning at $3.1 \mathrm{Ma}$. In Ruddiman, W.F., Kidd, R.B., Thomas, E., et al., Init. Repts. DSDP, 94, Pt. 2: Washington (U.S. Govt. Printing Office), 911-920.

Keigwin, L.D., Aubry, M.-P., and Kent, D.V., 1987. North Atlantic late Miocene stable-isotope stratigraphy, biostratigraphy and magnetostratigraphy. In Ruddiman, W.F., Kidd, R.B., Thomas, E., et al., Init. Repts. DSDP, 94, Pt. 2: Washington (U.S. Govt. Printing Office), 935-963.

Keir, R.S., 1988. On the late Pleistocene ocean geochemistry and circulation. Paleoceanography, 3:413-445. 
Koepnick, R.B., Denison, R.E., and Dahl, D.A., 1988. The Cenozoic ${ }^{87} \mathrm{Sr} /{ }^{86} \mathrm{Sr}$ curve: data review and implications for correlation of marine strata. Paleoceanography, 3:743-756.

Kroenke, L.W., Berger, W.H., Janecek, T.R., et al., 1991. Proc. ODP, Init. Repts., 130: College Station, Texas (Ocean Drilling Program).

Kroopnick, P.M., 1985. The distribution of ${ }^{13} \mathrm{C}$ of $\mathrm{CO}_{2}$ in the world oceans, Deep-Sea Res., Pt. A, 32:57-84.

Leinen, M., and Heath, G.R., 1981. Sedimentary indicators of atmospheric activity in the northern hemisphere during the Cenozoic. Palaeogeogr., Palaeoclimatol., Palaeoecol., 36:1-21.

Loubere, P., and Moss, K., 1986. Late Pliocene climatic change and the onset of Northern Hemisphere glaciation as recorded in the northeast Atlantic Ocean. Geol. Soc. Am. Bull., 97:818-828.

Lutze, G.F., Pflaumann, U., and Weinholz, P., 1986. Jungquartäre Fluktuationen der benthischen Foraminiferenfaunen in Tiefseesedimenten vor NW Afrika-Eine Reaktion auf Produktivitätsänderungen im Oberflächenwasser. "Meteor" Forschungsergeb., 40:163-180.

Lutze, G.F., and Thiel, H., 1989. Epibenthic foraminifera from elevated microhabitats: Cibicidoides wuellerstorfi and Planulina ariminensis. J. Foraminiferal Res., 19:153-158.

Maier-Reimer, E., Mikolajewicz, U., and Crowley, T., 1990. Ocean general circulation model sensitivity experiment with an open Central American Isthmus. Paleoceanography, 5:349-366.

Mammerickx, J., and Smith, S.M., 1985. Bathymetry of the North Central Pacific. Geol. Soc. Am., Map and Chart Ser., MC-52.

Martin, J.H., 1990. Glacial-interglacial $\mathrm{CO}_{2}$ change: the iron hypothesis. Paleoceanography, 5:1-13.

McCorkle, D.C., Keigwin, L.D., Corliss, B.H., and Emerson, S.R., 1990. The influence of microhabitats on the carbon isotopic composition of deep-sea benthic foraminifera. Paleoceanography, 5:161-185.

Miller, K.G. and Fairbanks, R.G., 1985. Oligocene to Miocene carbon isotope cycles and abyssal circulation changes. In Sundquist, E.T., and Broecker, W.S. (Eds.), The Carbon Cycle and Atmospheric $\mathrm{CO}_{2}$ : Natural Variations Archean to Present. Am. Geophys. Union, Geophys. Monogr. Ser., 32:469-486.

Palmer, M.R., and Elderfield, H., 1985. Sr isotope composition of sea water over the past 75 Myr. Nature, 314:526-528.

Peterson, L.C., and Backman, J., 1990. Late Cenozoic carbonate accumulation and the history of the carbonate compensation depth in the western equatorial Indian Ocean. In Duncan, R.A., Backman, J., Peterson, L.C., Peterson, L.C., et al., Proc. ODP, Sci. Results, 115: Washington (U.S. Govt. Printing Office), 467-507.

Pisias, N.G., Shackleton, N.J., and Hall, M.A., 1985. Stable isotope and calcium carbonate records from hydraulic piston cored Hole 574A: highresolution records from the middle Miocene. In Mayer, L., Theyer, F., Thomas, E., et al., Init. Repts. DSDP, 85: Washington (U.S. Govt. Printing Office), 735-748.

Prell, W.L., 1984. Covariance patterns of foraminiferal $\delta^{18} \mathrm{O}$ : an evaluation of Pliocene ice volume changes near 3.2 million years ago. Science, 226:692-693.

Ramanathan, V., Barkstrom, B.R., and Harrison, E.F., 1989. Climate and the earth's radiation budget. Phys. Today, 42:22-32.

Raymo, M.E., Ruddiman, W.F., Backman, J., Clement, B.M., and Martinson, D.G., 1989. Late Pliocene variation in Northern Hemisphere ice sheets and North Atlantic deep water circulation. Paleoceanography, 4:413-446.

Raymo, M.E., Ruddiman, W.F., Shackleton, N.J., and Oppo, D.W., 1990. Evolution of Atlantic-Pacific $\delta^{13} \mathrm{C}$ gradients over the last 2.5 m.y. Earth Planet. Sci. Lett., 97:353-368.

Redfield, A.C., Ketchum, B.H., and Richards, F.A., 1963. The influence of organisms on the composition of sea-water. In Hill, M.N. (Ed.), The Sea (Vol. 2): New York (Wiley-Interscience), 26-77.

Reid, J.L., 1965. Intermediate Waters of the Pacific Ocean. Johns Hopkins Oceanogr. Stud., No. 2.

Sarnthein, M., and Fenner, J., 1988. Global wind-induced change of deep-sea sediment budgets, new ocean production and $\mathrm{CO}_{2}$ reservoirs ca. 3.3-2.35 Ma BP. Philos. Trans. R. Soc. London Ser. B, 318:487-504.

Sarnthein, M., and Tiedemann, R., 1988. Toward a high-resolution stable isotope stratigraphy of the last 3.4 million years: Sites 658 and 659 off northwest Africa. In Ruddiman, W., Sarnthein, M., et al., Proc. ODP, Sci. Results, 108: College Station, TX (Ocean Drilling Program), 167-185.

Shackleton, N.J., 1977. Carbon-13 in Uvigerina: tropical rainforest history and the equatorial Pacific carbonate dissolution cycles. In Andersen, N.R., and Malahoff, A. (Eds.), The Fate of Fossil Fuel $\mathrm{CO}_{2}$ in the Oceans: New York (Plenum), 401-427.
Shackleton, N.J., Backman, J., Zimmerman, H., Kent, D.V., Hall, M.A. Roberts, D.G., Schnitker, D., Baldauf, J.G., Desprairies, A., Homrighausen, R., Huddlestun, P., Keene, J.B., Kaltenback, A.J., Krumsiek, K.A.O., Morton, A.C., Murray, J.W., and Westburg-Smith, J., 1984. Oxygen isotope calibration of the onset of ice-rafting and history of glaciation in the North Atlantic region. Nature, 307:620-623.

Shackleton, N.J., Berger, A., and Peltier, W.R., 1990. An alternative astronomical calibration of the lower Pleistocene time scale based on ODP Site 677. Trans. R. Soc. Edinburgh: Earth Sci., 81:251-261.

Shackleton, N.J., and Hall, M.A., 1984. Oxygen and carbon isotope stratigraphy of Deep Sea Drilling Project Hole 552A: Plio-Pleistocene glacial history. In Roberts, D.G., Schnitker, D., et al., Init. Repts. DSDP, 81: Washington (U.S. Govt. Printing Office), 599-609.

Shackleton, N.J., Hall, M.A., Line, J., and Shuxi, C., 1983. Carbon isotope data in Core V19-30 confirm reduced carbon dioxide concentration in the ice age atmosphere. Nature, 306:319-322.

Shackleton, N.J., Imbrie, J., and Hall, M., 1983. Oxygen and carbon isotope record of east Pacific Core V19-30: implications for the formation of deep water in the late Pleistocene North Atlantic. Earth Planet. Sci. Lett., 65:233-266.

Shackleton, N.J., and Opdyke, N.D., 1973. Oxygen isotope and paleomagnetic stratigraphy of equatorial Pacific Core V28-238: oxygen isotope temperatures and ice volumes on a $10^{5}$ and $10^{6}$ year scale. Quat. Res., 3:39-55.

, 1976. Oxygen-isotope and paleomagnetic stratigraphy of Pacific Core V28-239 late Pliocene to latest Pleistocene. In Cline, R.M., and Hays, J.D. (Eds.), Investigation of Late Quaternary Paleoceanography and Paleoclimatology. Mem.-Geol. Soc. Am., 145:449-464.

Shackleton, N.J., and Vincent, E., 1978. Oxygen and carbon isotope studies in Recent foraminifera from the southwest Indian Ocean. Mar. Micropaleontol., 3:1-13.

Shipboard Scientific Party, 1986. Site 586. In Moberly, R., Schlanger, S.O., et al. Init. Repts. DSDP, 89: Washington (U.S. Govt. Printing Office), 213-235.

Spero, H.J., and Williams, D.F., 1988. Extracting environmental information from planktonic foraminiferal $\delta^{13} \mathrm{C}$ data. Nature, 335:717-719.

Streeter, S.S., and Shackleton, N.J., 1979. Paleocirculation of the deep North Atlantic: 15,000-year record of benthic foraminifera and oxygen-18. Science, 203:168-171.

Sverdrup, H.U., Johnson, M.W., and Fleming, R.H., 1942. The Oceans: Their Physics, Chemistry and General Biology: Englewood Cliffs, NJ (Prentice-Hall).

Tappan, H., 1968. Primary production, isotopes, extinctions and the atmosphere. Palaeogeogr., Palaeoclimatol., Palaeoecol., 4:187-210.

Tiedemann, R., 1991. Acht Millionen Jahre Klimageschichte von Nordwest Afrika und Paläo-Ozeanographie des angrenzenden Atlantiks: Hochauflösende Zeitreihen von ODP-Sites 658-661. Ber. Repts., Geol.-Paläont. Inst. Univ. Kiel, 46:1-190.

Vincent, E., and Berger, W.H., 1985. Carbon dioxide and polar cooling in the Miocene: the Monterey hypothesis. In Sundquist, E.T., and Broecker, W.S. (Eds.), The Carbon Cycle and Atmospheric $\mathrm{CO}_{2}$ : Natural Variations Archean to Present. Am. Geophys. Union, Geophys. Monogr. Ser., 32:455-468.

Vincent, E., Killingley, J.S., and Berger, W.H., 1980. The Magnetic Epoch-6 Carbon Shift: a change in the ocean's ${ }^{13} \mathrm{C} /{ }^{12} \mathrm{C}$ ratio 6.2 million years ago. Mar. Micropaleontol., 5:185-203.

1981. Stable isotope composition of benthic foraminifera from the equatorial Pacific. Nature, 289:639-643.

Wefer, G., and Berger, W.H., 1991. Isotope paleontology: growth and composition of extant calcareous species. Mar. Geol., 100:207-248.

Whitman, J.M., 1989. Stable isotope record of foraminifera from Ontong Java Plateau for the last 6 million years, DSDP Site 586 [Ph.D. dissert.]. Univ. of California, San Diego.

Whitman, J.M., and Berger, W.H., 1992. Pliocene-Pleistocene oxygen isotope record Site 586, Ontong Java Plateau. Mar. Micropaleontol., 18:171-198.

Williams, D.F., Sommer, M.A., and Bender, M.L., 1977. Carbon isotopic compositions of recent planktonic foraminifera of the Indian Ocean. Earth Planet. Sci. Lett., 36:391-403.

Winterer, E.L., Riedel, W.R., et al., Init. Repts. DSDP, 7: Washington (U.S. Govt. Printing Office).

Woodruff, F., and Savin, S.M., 1985. $\delta^{13} \mathrm{C}$ values of Miocene Pacific benthic foraminifera: correlations with sea level and biological productivity. $G e$ ology, 13:119-122.

Woodruff, J., Savin, S.M., and Douglas, R.G., 1980. Biological fractionation of oxygen and carbon isotopes by recent benthic foraminifera. Mar. Micropaleontol., 5:3-11. 
Wu, G., and Berger, W.H., 1989. Planktonic foraminifera: differential dissolution and the Quaternary stable isotope record in the west-equatorial Pacific. Paleoceanography, 4:181-198.

1991. Pleistocene $\delta^{18} \mathrm{O}$ records from Ontong-Java Plateau: effects of winnowing and dissolution. Mar. Geol., 96:193-209.

Wu, G., Herguera, J.C., and Berger, W.H., 1990. Differential dissolution: modification of late Pleistocene oxygen isotope records in the western equatorial Pacific. Paleoceanography, 5:581-594.
Zahn, R., Winn, K., and Sarnthein, M., 1986. Benthic foraminiferal $\delta^{13} \mathrm{C}$ and accumulation rates of organic carbon: Uvigerina peregrina group and Cibicidoides wuellerstorfi. Paleoceanography, 1:27-42.

Date of initial receipt: 9 March 1992

Date of acceptance: 31 August 1992

Ms 130B-030

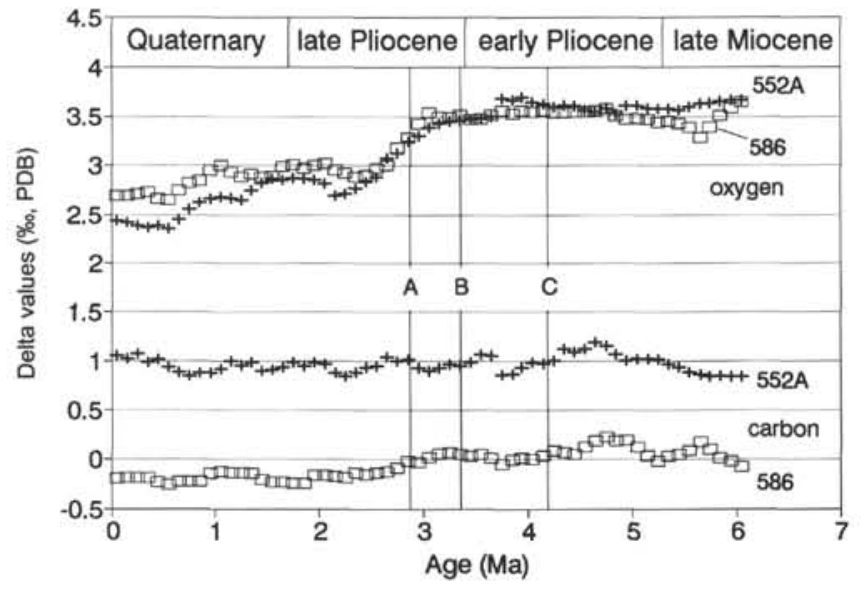

Figure 11. Comparison of North Atlantic isotope record (Site 552) with the Ontong Java record (Site 586). Data for Hole 552A from Shackleton and Hall (1984), Shackleton et al. (1984), Keigwin (1984), and Keigwin et al. (1987). The sampling interval at Hole $552 \mathrm{~A}$ was $10 \mathrm{~cm}$ in the upper and lower sections of the hole; between 3.5 and $5.0 \mathrm{Ma}$, the sampling interval was generally 1.5 $\mathrm{m}$, although sometimes it was larger. Data given in Shackleton and Hall (1984) for various benthic species were converted to $P$. wuellerstorfi equivalents using average offset values. Correlation of the records is based on the time scale of Berggren et al. (1985) and on available paleomagnetic data (Shackleton and Hall, 1984; Keigwin et al., 1987). Constant sedimentation rates were assumed between age control points, and data were smoothed by calculating sliding averages. Note increased asymmetry after the major cooling event (Event A). 
APPENDIX A

Grain-size Data, Sand Fractions

\begin{tabular}{|c|c|c|c|c|c|c|c|c|c|c|c|c|c|}
\hline $\begin{array}{l}\text { Core, section, } \\
\text { interval }(\mathrm{cm})\end{array}$ & $\begin{array}{l}\text { Depth } \\
\text { (m) }\end{array}$ & $\begin{array}{c}\text { Age } \\
(\mathrm{m.y.})\end{array}$ & $\begin{array}{l}\text { Weight } \\
\text { (g) }\end{array}$ & $>63 \mu \mathrm{m}$ & $\begin{array}{l}\text { Weight percent } \\
>149 \mu \mathrm{m}\end{array}$ & $>250 \mu \mathrm{m}$ & $\begin{array}{l}\text { Core, section, } \\
\text { interval }(\mathrm{cm})\end{array}$ & $\begin{array}{l}\text { Depth } \\
\text { (m) }\end{array}$ & $\begin{array}{c}\text { Age } \\
\text { (m.y.) }\end{array}$ & $\begin{array}{l}\text { Weight } \\
\text { (g) }\end{array}$ & $>63 \mu \mathrm{m}$ & $\begin{array}{l}\text { Weight percent } \\
>149 \mu \mathrm{m}\end{array}$ & $>250 \mu \mathrm{m}$ \\
\hline 89-586- & & & & & & & $7-1,50-52$ & 97.41 & 3.83 & 6.2921 & 23.7 & 13.9 & 8.8 \\
\hline $1-1,49-52$ & 0.50 & 0.02 & 4.9582 & 32.7 & 23.2 & 19.0 & $7-2,48-50$ & 98.89 & 3.86 & 7.5131 & 30.5 & 20.4 & 14.5 \\
\hline $2-1,50-52$ & 1.81 & 0.09 & 5.3462 & 35.4 & 25.7 & 19.2 & $7-3,50-52$ & 100.41 & 3.90 & 6.2216 & 21.6 & 14.0 & 10.2 \\
\hline $2-2,55-57$ & 3.36 & 0.16 & 2.4318 & 33.6 & 24.0 & 17.2 & $7-4,50-52$ & 101.91 & 3.93 & 7.0766 & 21.6 & 14.1 & 10.4 \\
\hline $2-3,55-57$ & 4.86 & 0.23 & 4.4559 & 27.5 & 21.4 & 17.4 & $7-5,50-52$ & 103.41 & 3.97 & 6.1806 & 22.5 & 14.0 & 10.1 \\
\hline $2-4.55-57$ & 6.36 & 0.30 & 5.5078 & 34.3 & 25.2 & 20.1 & $7-6,48-50$ & 104.89 & 4.00 & 6.4870 & 14.7 & 8.7 & 5.6 \\
\hline $2-5,55-57$ & 7.86 & 0.37 & 3.9996 & 21.8 & 16.0 & 12.9 & $8-1,50-52$ & 107.01 & 4.05 & 8.5136 & 25.2 & 16.8 & 12.1 \\
\hline $2-6,55-57$ & 9.36 & 0.44 & 3.7027 & 40.8 & 29.1 & 21.9 & $8-2,48-50$ & 108.49 & 4.09 & 9.0032 & 23.5 & 14.1 & 9.8 \\
\hline $3-1,50-52$ & 11.32 & 0.54 & 6.1348 & 27.4 & 18.8 & 14.5 & $8-3,50-52$ & 110.01 & 4.12 & 5.4969 & 16.9 & 10.5 & 6.5 \\
\hline $3-2,49-50$ & 12.81 & 0.61 & 5.9064 & 21.9 & 14.6 & 10.8 & $8-4,50-52$ & 111.51 & 4.16 & 8.0001 & 13.1 & 8.3 & 5.5 \\
\hline $3-3,50-52$ & 14.31 & 0.68 & 5.6263 & 29.0 & 17.1 & 12.0 & $8-5,50-52$ & 113.01 & 4.19 & 9.2394 & 21.4 & 12.9 & 8.4 \\
\hline $3-4,50-52$ & 15.81 & 0.75 & 4.0681 & 8.5 & 6.3 & 5.1 & & & & & & & \\
\hline $3-5,50-52$ & 17.31 & 0.81 & 5.6486 & 41.6 & 31.5 & 25.1 & $89-586-$ & & & & & & \\
\hline $3-6,51-53$ & 18.82 & 0.88 & 4.2319 & 31.1 & 23.0 & 18.1 & $8-6,48-50$ & 114.49 & 4.23 & 6.9550 & 28.7 & 19.7 & 13.3 \\
\hline $4-1,50-52$ & 20.81 & 0.97 & 6.9007 & 31.2 & 22.5 & 17.0 & $9-1,50-52$ & 116.61 & 4.28 & 4.9866 & 13.8 & 8.2 & 4.9 \\
\hline $4-2,51-53$ & 22.32 & 1.03 & 7.2806 & 31.5 & 23.6 & 17.8 & $9-2,48-50$ & 118.09 & 4.31 & 4.9608 & 18.0 & 11.6 & 6.8 \\
\hline $4-3,50-52$ & 23.81 & 1.10 & 6.4016 & 27.9 & 21.4 & 16.3 & $9-3,50-52$ & 119.61 & 4.35 & 4.8377 & 23.2 & 14.5 & 8.3 \\
\hline $4-4,50-52$ & 25.31 & 1.17 & 6.3281 & 29.2 & 22.6 & 16.7 & $9-4,50-52$ & 121.11 & 4.38 & 3.9128 & 19.6 & 12.0 & 7.5 \\
\hline $4-5,50-52$ & 26.81 & 1.23 & 7.1005 & 24.3 & 17.4 & 12.4 & $9-5,50-52$ & 122.61 & 4.42 & 5.2363 & 18.6 & 11.8 & 7.7 \\
\hline $4-6,51-53$ & 28.32 & 1.30 & 6.8403 & 24.7 & 16.3 & 10.6 & $9-6,48-50$ & 124.09 & 4.45 & 3.8104 & 17.9 & 11.4 & 7.7 \\
\hline $5-1,60-62$ & 30.41 & 1.39 & 7.7426 & 21.8 & 15.9 & 12.1 & $10-1,50-52$ & 126.21 & 4.50 & 6.1091 & 19.8 & 13.1 & 9.5 \\
\hline $5-2,60-62$ & 31.91 & 1.46 & 7.3019 & 23.6 & 15.5 & 10.8 & $10-2,48-50$ & 127.69 & 4.54 & 6.7212 & 22.7 & 12.8 & 7.7 \\
\hline $5-3,58-60$ & 33.39 & 1.52 & 6.9758 & 27.6 & 19.2 & 12.3 & $10-3,50-52$ & 129.21 & 4.57 & 5.2492 & 23.8 & 13.8 & 8.5 \\
\hline $5-4,60-62$ & 34.91 & 1.59 & 6.4803 & 29.6 & 22.6 & 17.4 & $10-4,50-52$ & 130.71 & 4.61 & 6.4590 & 16.1 & 9.3 & 5.7 \\
\hline $5-5,60-62$ & 36.41 & 1.65 & 6.5577 & 39.0 & 29.9 & 23.3 & $10-5,50-52$ & 132.21 & 4.64 & 6.9867 & 27.3 & 16.3 & 10.0 \\
\hline \multirow[t]{2}{*}{$5-6,60-62$} & 37.91 & 1.72 & 6.3180 & 22.3 & 16.4 & 12.3 & $10-6,48-50$ & 133.69 & 4.68 & 6.2724 & 27.1 & 16.7 & 11.0 \\
\hline & & & & & & & $11-1,50-52$ & 135.81 & 4.73 & 5.6202 & 27.1 & 15.4 & 9.6 \\
\hline $89-586 \mathrm{~A}-$ & & & & & & & $11-2,48-50$ & 137.29 & 4.76 & 5.5076 & 38.7 & 26.5 & 19.8 \\
\hline $1-1,50-52$ & 39.81 & 1.80 & 6.3186 & 16.3 & 11.4 & 8.1 & $11-3,50-52$ & 138.81 & 4.80 & 5.7270 & 27.6 & 14.7 & 8.4 \\
\hline $1-2,48-50$ & 41.29 & 1.87 & 5.2806 & 29.1 & 23.5 & 18.6 & $11-4,50-52$ & 140.31 & 4.83 & 4.8332 & 27.9 & 16.7 & 11.2 \\
\hline $1-3,50-52$ & 42.81 & 1.93 & 5.0281 & 13.4 & 9.4 & 6.4 & $11-5,50-52$ & 141.81 & 4.87 & 7.5542 & 21.0 & 11.7 & 7.4 \\
\hline $1-4,50-52$ & 44.31 & 2.00 & 4.6882 & 23.3 & 17.2 & 12.5 & $11-6,48-50$ & 143.31 & 4.90 & 6.5045 & 21.9 & 10.8 & 6.7 \\
\hline $1-5,50-52$ & 45.81 & 2.07 & 6.2007 & 18.7 & 12.8 & 9.5 & $12-1,50-52$ & 145.41 & 4.95 & 5.0023 & 20.2 & 12.2 & 8.7 \\
\hline $1-6,48-50$ & 47.29 & 2.13 & 5.4905 & 18.9 & 12.8 & 9.5 & $12-2,48-50$ & 146.89 & 4.99 & 5.8149 & 14.7 & 8.3 & 5.2 \\
\hline $2-1,50-52$ & 49.41 & 2.22 & 5.6157 & 36.6 & 26.1 & 19.5 & $12-3,50-52$ & 148.41 & 5.02 & 4.5786 & 14.9 & 9.1 & 6.0 \\
\hline $2-2,48-50$ & 50.89 & 2.29 & 4.2093 & 27.3 & 18.8 & 12.5 & $12-4,50-52$ & 149.91 & 5.06 & 4.1751 & 10.7 & 5.8 & 3.6 \\
\hline $2-3,50-52$ & 52.41 & 2.36 & 4.7954 & 6.3 & 3.8 & 2.4 & $12-5,50-52$ & 151.41 & 5.09 & 3.6159 & 15.9 & 8.1 & 4.6 \\
\hline $2-4,50-52$ & 53.91 & 2.42 & 4.4544 & 18.8 & 12.3 & 8.7 & $12-6,48-50$ & 152.89 & 5.13 & 4.0398 & 19.2 & 8.7 & 4.4 \\
\hline $2-5,50-52$ & 55.41 & 2.49 & 5.7305 & 12.0 & 7.4 & 5.1 & $13-1,50-52$ & 155.01 & 5.18 & 6.6383 & 21.7 & 13.3 & 7.9 \\
\hline $2-6,48-50$ & 56.89 & 2.55 & 7.1420 & 15.3 & 9.9 & 6.9 & $13-2,48-50$ & 156.49 & 5.21 & 4.8821 & 20.0 & 11.1 & 6.1 \\
\hline $3-1,50-52$ & 59.01 & 2.65 & 4.9387 & 21.2 & 13.0 & 8.5 & $13-3,50-52$ & 158.01 & 5.25 & 5.4100 & 16.0 & 9.4 & 6.0 \\
\hline $3-2,48-50$ & 60.49 & 2.71 & 5.7080 & 13.1 & 7.6 & 5.2 & $13-4,50-52$ & 159.51 & 5.28 & 3.1605 & 11.5 & 7.1 & 4.7 \\
\hline $3-3,50-52$ & 62.01 & 2.78 & 5.3798 & 11.1 & 7.0 & 5.1 & $13-5,50-52$ & 161.01 & 5.32 & 6.6119 & 17.1 & 11.0 & 7.6 \\
\hline $3-4,50-52$ & 63.51 & 2.84 & 3.7578 & 22.4 & 15.4 & 10.9 & $14-1,50-52$ & 162.80 & 5.36 & 6.4087 & 17.4 & 11.6 & 8.3 \\
\hline $3-5,50-52$ & 65.01 & 2.91 & 3.4350 & 14.8 & 10.2 & 7.7 & $14-2,48-50$ & 163.79 & 5.38 & 6.7274 & 17.7 & 10.0 & 6.7 \\
\hline $3-6,48-50$ & 66.49 & 2.95 & 5.6336 & 24.3 & 16.9 & 12.6 & $14-3,50-52$ & 165.31 & 5.42 & 6.2947 & 18.8 & 9.9 & 6.5 \\
\hline $4-1,50-52$ & 68.61 & 3.01 & 4.2946 & 21.5 & 14.0 & 10.2 & $15-1,50-52$ & 167.21 & 5.46 & 5.7303 & 16.4 & 7.5 & 4.8 \\
\hline $4-2,48-50$ & 70.09 & 3.05 & 6.4669 & 22.2 & 15.2 & 11.2 & $15-2,48-50$ & 168.69 & 5.50 & 6.2132 & 18.3 & 10.4 & 6.8 \\
\hline $4-3,50-52$ & 71.61 & 3.09 & 5.7123 & 26.7 & 18.3 & 13.3 & $15-3,50-52$ & 170.21 & 5.53 & 5.5913 & 25.0 & 16.0 & 10.9 \\
\hline $4-4,50-52$ & 73.11 & 3.14 & 7.1425 & 28.1 & 19.8 & 15.0 & $15-4,50-52$ & 171.71 & 5.57 & 5.6239 & 18.8 & 9.6 & 5.8 \\
\hline $4-5,50-52$ & 74.64 & 3.18 & 4.9827 & 22.9 & 15.5 & 11.5 & $15-5,50-52$ & 173.21 & 5.61 & 5.6734 & 18.3 & 11.0 & 7.0 \\
\hline $4-6,48-50$ & 76.09 & 3.22 & 7.5269 & 20.2 & 12.9 & 9.2 & $15-6,50-52$ & 174.71 & 5.64 & 6.1248 & 22.1 & 13.4 & 9.1 \\
\hline $5-1,50-52$ & 78.21 & 3.28 & 6.1301 & 23.4 & 15.8 & 12.2 & $16-1,50-52$ & 175.70 & 5.66 & 2.9380 & 21.5 & 13.8 & 9.0 \\
\hline $5-2,48-50$ & 79.69 & 3.33 & 5.8656 & 21.5 & 13.6 & 10.0 & $16-2,50-52$ & 177.71 & 5.71 & 4.6305 & 23.3 & 15.3 & 10.4 \\
\hline $5-3,50-52$ & 81.21 & 3.37 & 5.0095 & 23.8 & 15.6 & 11.3 & $16-3,50-52$ & 179.21 & 5.75 & 4.0192 & 25.5 & 18.1 & 12.9 \\
\hline $5-4,50-52$ & 82.71 & 3.41 & 5.2923 & 12.6 & 7.0 & 5.0 & $16-4,50-52$ & 180.71 & 5.78 & 3.3011 & 20.6 & 13.9 & 9.8 \\
\hline $5-5,50-52$ & 84.21 & 3.45 & 6.1639 & 28.0 & 18.3 & 12.7 & $16-5,50-52$ & 182.21 & 5.82 & 3.3938 & 18.0 & 10.5 & 6.3 \\
\hline $5-6,48-50$ & 85.69 & 3.50 & 5.0276 & 26.1 & 16.9 & 12.9 & $16-6,50-52$ & 183.71 & 5.85 & 3.6890 & 20.5 & 13.7 & 8.7 \\
\hline $6-1,50-52$ & 87.81 & 3.56 & 5.1638 & 28.7 & 19.2 & 14.3 & $17-1,50-52$ & 185.81 & 5.90 & 5.3367 & 21.6 & 14.5 & 9.1 \\
\hline $6-2,48-50$ & 89.29 & 3.60 & 5.7177 & 33.0 & 22.3 & 16.8 & $17-2,50-52$ & 187.31 & 5.94 & 4.1288 & 18.4 & 13.9 & 7.3 \\
\hline $6-3,50-52$ & 90.81 & 3.64 & 4.9969 & 18.3 & 11.8 & 8.9 & $17-3,50-52$ & 188.81 & 5.97 & 6.3419 & 25.5 & 17.0 & 11.3 \\
\hline $6-4,50-52$ & 92.31 & 3.69 & 4.5510 & 27.3 & 18.0 & 13.5 & $17-4,50-52$ & 190.31 & 6.01 & 3.8403 & 23.7 & 16.6 & 11.6 \\
\hline $6-5,50-52$ & 93.81 & 3.73 & 3.0755 & 26.1 & 17.1 & 13.4 & $17-5,50-52$ & 191.81 & 6.04 & 3.9266 & 24.4 & 16.3 & 11.0 \\
\hline $6-6,50-52$ & 95.31 & 3.77 & 5.4780 & 17.0 & 10.7 & 7.7 & $17-6,50-52$ & 193.31 & 6.08 & 5.4382 & 15.2 & 10.3 & 7.2 \\
\hline
\end{tabular}


APPENDIX B

Benthic Foraminifer Counts

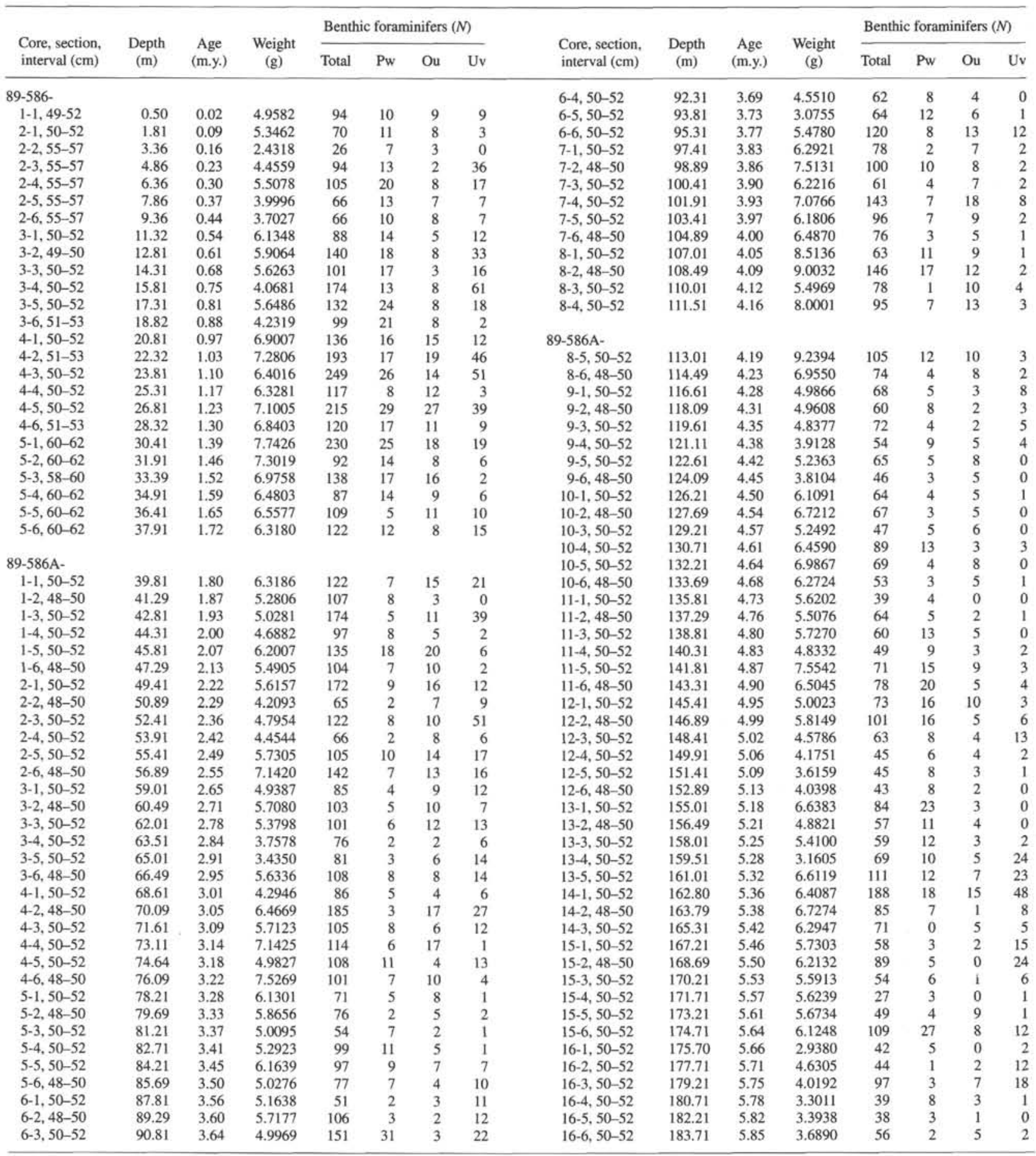

Notes: $\mathrm{Pw}=$ Planulina wuellerstorfi, $\mathrm{Ou}=$ Oridorsalis umbonatus, and $\mathrm{Uv}=$ Uvigerina $\operatorname{spp} . \mathrm{N}=$ number of samples. 
APPENDIX C

Isotope Data (\%), Four Foraminifer Taxa

\begin{tabular}{|c|c|c|c|c|c|c|c|c|c|c|c|c|c|c|c|c|c|c|c|}
\hline \multirow{2}{*}{$\begin{array}{l}\text { Depth } \\
\text { (m) }\end{array}$} & \multirow{2}{*}{$\begin{array}{c}\text { Age } \\
\text { (m.y.) }\end{array}$} & \multicolumn{2}{|c|}{ G. sacculifer } & Pullen & a spp. & P. wue & rstorfi & O. um & onatus & & & G. sa & alifer & Pulleni & a spp. & P. whe & rstorfi & O. um & onatus \\
\hline & & $\delta^{18} \mathrm{O}$ & $\delta^{13} \mathrm{C}$ & $\delta^{18} \mathrm{O}$ & $8^{13} \mathrm{C}$ & $\delta^{18} \mathrm{O}$ & $\delta^{13} \mathrm{C}$ & $\delta^{18} \mathrm{O}$ & $8^{13} \mathrm{C}$ & (m) & (m.y.) & $\delta^{18} \mathrm{O}$ & $8^{13} \mathrm{C}$ & $8^{18} \mathrm{O}$ & $8^{13} \mathrm{C}$ & $8^{18} \mathrm{O}$ & $\delta^{13} \mathrm{C}$ & $\delta^{18} \mathrm{O}$ & $\delta^{13} \mathrm{C}$ \\
\hline 0.50 & 0.02 & -1.48 & 2.00 & -0.77 & 1.24 & 2.90 & 0.08 & 3.73 & -1.15 & 90.81 & 3.64 & -1.73 & 1.78 & -1.46 & 0.76 & 2.55 & -0.06 & 3.08 & -0.79 \\
\hline 1.81 & 0.09 & -0.83 & 1.59 & -0.13 & 1.10 & 3.61 & -0.49 & 4.54 & -1.34 & 92.31 & 3.69 & -1.80 & 1.61 & -1.41 & 0.62 & 2.62 & -0.15 & 3.03 & -1.10 \\
\hline 3.36 & 0.16 & -1.49 & 1.68 & -0.75 & 0.97 & 3.04 & -0.15 & & & 93.81 & 3.73 & -1.73 & 1.85 & -1.23 & 0.81 & 2.46 & -0.06 & 3.07 & -1.10 \\
\hline 4.86 & 0.23 & -0.83 & 1.82 & -0.24 & 1.35 & 3.69 & -0.34 & & & 93.81 & 3.73 & & & -1.15 & 0.60 & & & & \\
\hline 6.36 & 0.30 & -1.07 & 1.70 & -0.68 & 1.09 & 3.30 & -0.03 & 3.93 & -1.58 & 95.31 & 3.77 & -1.65 & 1.50 & -1.35 & 0.55 & 2.60 & 0.18 & 3.23 & -1.13 \\
\hline 7.86 & 0.37 & -1.23 & 1.72 & -0.90 & 0.88 & 3.29 & -0.15 & 3.92 & -1.15 & 95.31 & 3.77 & & & -1.35 & 0.53 & & & & \\
\hline 9.36 & 0.44 & -1.05 & 1.36 & -0.73 & 0.62 & 3.20 & -0.17 & 3.83 & -1.55 & 97.41 & 3.83 & -1.42 & 2.03 & -1.20 & 0.60 & & & 3.02 & -1.09 \\
\hline 11.32 & 0.54 & -1.29 & 1.80 & -0.84 & 0.98 & 3.08 & -0.21 & 3.93 & -1.41 & 97.41 & 3.83 & -1.55 & 2.07 & & & & & & \\
\hline 11.32 & 0.54 & & & -0.80 & 1.01 & & & & & 98.89 & 3.86 & -1.65 & 1.71 & -1.29 & 0.64 & 2.37 & 0.02 & 3.12 & -0.76 \\
\hline 12.81 & 0.61 & -1.44 & 1.29 & -0.96 & 0.77 & 3.29 & -0.32 & 3.86 & -1.13 & 100.41 & 3.90 & -1.67 & 1.43 & -1.43 & 0.51 & 2.28 & -0.20 & 2.92 & -1.31 \\
\hline 12.81 & 0.61 & & & -1.10 & 0.61 & & & & & 101.91 & 3.93 & -1.50 & 1.50 & -1.33 & 0.85 & 2.63 & -0.13 & 3.17 & -1.24 \\
\hline 14.31 & 0.68 & -1.13 & 0.78 & -0.64 & 0.64 & 3.54 & -0.41 & & & 103.41 & 3.97 & -1.70 & 1.54 & -1.43 & 0.58 & 2.32 & -0.15 & 2.83 & -1.26 \\
\hline 14.31 & 0.68 & & & -0.58 & 0.52 & & & & & 104.89 & 4.00 & -1.62 & 1.93 & -1.40 & 0.74 & 2.44 & -0.01 & 2.93 & -1.01 \\
\hline 15.81 & 0.75 & -0.91 & 1.53 & -0.18 & 1.29 & 3.69 & -0.21 & 4.09 & -1.58 & 107.01 & 4.05 & -1.30 & 1.66 & -0.99 & 1.04 & 2.54 & 0.23 & 3.06 & -0.81 \\
\hline 15.81 & 0.75 & & & -0.28 & 1.15 & & & & & 107.01 & 4.05 & -1.55 & 2.07 & & & & & & \\
\hline 17.31 & 0.81 & -1.36 & 1.68 & -0.87 & 0.59 & 2.83 & -0.09 & 3.69 & -1.22 & 108.49 & 4.09 & -1.39 & 2.01 & -1.04 & 0.93 & 2.44 & 0.17 & 2.96 & -1.04 \\
\hline 17.31 & 0.81 & & & -0.91 & 1.00 & & & & & 110.01 & 4.12 & -1.65 & 1.94 & -1.00 & 0.83 & & & 3.15 & -0.77 \\
\hline 18.82 & 0.88 & -1.16 & 1.61 & -0.79 & 0.67 & 3.10 & -0.14 & 3.67 & -1.18 & 111.51 & 4.16 & -1.49 & 1.79 & -0.95 & 0.86 & 2.39 & 0.06 & 3.21 & -0.98 \\
\hline 20.81 & 0.97 & -1.75 & 1.50 & -0.80 & 0.61 & 2.66 & -0.18 & 3.22 & -1.58 & 113.01 & 4.19 & -1.54 & 1.73 & -1.10 & 0.86 & 2.36 & 0.04 & 3.08 & -1.16 \\
\hline 20.81 & 0.97 & & & -0.88 & 0.56 & & & & & 114.49 & 4.23 & -1.28 & 2.02 & -1.00 & 0.85 & 2.44 & -0.02 & 3.10 & -1.15 \\
\hline 22.32 & 1.03 & -1.06 & 1.90 & -1.02 & 1.13 & 2.85 & -0.08 & 3.67 & -1.20 & 116.61 & 4.28 & -1.18 & 1.81 & -0.85 & 0.88 & 2.71 & 0.00 & & \\
\hline 23.81 & 1.10 & -1.28 & 1.64 & -0.81 & 0.54 & 3.23 & -0.34 & 4.13 & -1.02 & 118.09 & 4.31 & -1.24 & 2.20 & -0.94 & 1.04 & 2.41 & 0.30 & & \\
\hline 25.31 & 1.17 & -1.28 & 1.61 & -1.16 & 0.99 & 2.94 & 0.07 & 3.46 & -0.73 & 119.61 & 4.35 & -1.29 & 1.95 & -0.87 & 0.69 & 2.38 & 0.29 & & \\
\hline 25.31 & 1.17 & -1.64 & 1.61 & & & & & & & 121.11 & 4.38 & -1.31 & 2.05 & -0.99 & 0.71 & 2.42 & 0.00 & 3.09 & -0.82 \\
\hline 26.81 & 1.23 & -1.23 & 1.61 & -0.47 & 1.05 & 3.37 & -0.13 & 3.89 & -1.22 & 122.61 & 4.42 & -1.17 & 1.83 & -0.93 & 0.53 & 2.58 & -0.08 & 3.27 & -1.42 \\
\hline 28.32 & 1.30 & -1.33 & 1.79 & -1.03 & 0.83 & 2.98 & -0.10 & 3.65 & -1.14 & 124.09 & 4.45 & -1.11 & 1.75 & -0.91 & 0.62 & & & 3.05 & -1.40 \\
\hline 30.41 & 1.39 & -1.36 & 1.88 & -0.43 & 0.86 & 3.39 & -0.14 & 4.12 & -1.32 & 126.21 & 4.50 & -1.17 & 1.84 & -1.09 & 0.64 & & & & \\
\hline 31.91 & 1.46 & -1.15 & 1.78 & -0.88 & 0.83 & 3.01 & -0.17 & 3.78 & -1.26 & 127.69 & 4.54 & -1.22 & 2.15 & -0.99 & 0.62 & & & 2.92 & -1.22 \\
\hline 33.39 & 1.52 & -1.17 & 1.54 & -0.68 & 0.48 & 2.92 & -0.36 & 3.67 & -1.15 & 129.21 & 4.57 & -1.24 & 1.91 & -1.01 & 0.69 & 2.47 & 0.02 & 2.98 & -1.30 \\
\hline 34.91 & 1.59 & -1.30 & 1.73 & -0.90 & 0.89 & 2.92 & -0.16 & 3.73 & -1.07 & 130.71 & 4.61 & -1.24 & 1.58 & -1.18 & 0.38 & 2.40 & -0.22 & & \\
\hline 36.41 & 1.65 & -0.92 & 1.62 & -0.64 & 0.76 & 3.18 & -0.35 & 3.93 & -1.08 & 132.21 & 4.64 & -1.08 & 2.17 & -1.09 & 0.81 & 2.27 & 0.19 & 2.80 & -1.04 \\
\hline 37.91 & 1.72 & -1.27 & 1.48 & -0.98 & 0.77 & 3.24 & -0.31 & 3.77 & -0.98 & 133.69 & 4.68 & -1.10 & 1.90 & -1.11 & 0.71 & & & 3.05 & -1.22 \\
\hline 39.81 & 1.80 & -0.83 & 1.67 & -0.87 & 0.80 & 3.06 & -0.14 & 3.58 & -1.22 & 135.81 & 4.73 & -1.24 & 2.12 & -1.00 & 0.94 & 2.53 & 0.34 & & \\
\hline 39.81 & 1.80 & -1.24 & 1.56 & & & & & & & 137.29 & 4.76 & -1.34 & 2.25 & -0.95 & 1.14 & 2.57 & 0.37 & & \\
\hline 41.29 & 1.87 & -1.31 & 1.94 & -1.18 & 0.84 & 2.75 & -0.13 & 3.47 & -0.90 & 138.81 & 4.80 & -1.31 & 2.09 & -1.10 & 0.98 & 2.41 & 0.31 & & \\
\hline 42.81 & 1.93 & -1.00 & 1.61 & -0.85 & 0.39 & & & 4.10 & -1.50 & 140.31 & 4.83 & -1.34 & 2.10 & -0.94 & 0.96 & 2.30 & 0.40 & & \\
\hline 44.31 & 2.00 & -1.16 & 1.76 & -1.04 & 0.51 & 2.88 & -0.26 & 3.44 & -1.25 & 141.81 & 4.87 & -1.22 & 2.18 & -0.95 & 0.95 & 2.45 & 0.34 & 2.81 & -1.26 \\
\hline 45.81 & 2.07 & -1.13 & 2.17 & -1.05 & 0.64 & 3.09 & -0.27 & 3.96 & -1.19 & 143.31 & 4.90 & -1.38 & 2.22 & -1.14 & 0.97 & 2.37 & 0.12 & & \\
\hline 47.29 & 2.13 & -1.37 & 1.96 & -1.23 & 0.87 & 2.98 & 0.14 & 3.60 & -0.87 & 145.41 & 4.95 & -1.19 & 2.51 & -0.96 & 1.28 & 2.43 & 0.40 & 2.78 & -0.98 \\
\hline 49.41 & 2.22 & -1.10 & 1.53 & -1.03 & 0.43 & 3.10 & -0.31 & 3.69 & -1.69 & 146.89 & 4.99 & -1.33 & 2.37 & -1.21 & 0.74 & 2.46 & 0.24 & & \\
\hline 50.89 & 2.29 & -1.20 & 2.04 & -1.10 & 0.78 & & & 3.43 & -1.17 & 148.41 & 5.02 & -1.17 & 2.16 & -0.91 & 0.39 & 2.81 & -0.10 & & \\
\hline 50.89 & 2.29 & -1.54 & 1.67 & & & & & & & 149.91 & 5.06 & -1.24 & 2.09 & -0.90 & 0.66 & 2.80 & -0.02 & & \\
\hline 52.41 & 2.36 & -1.00 & 1.90 & -0.89 & 0.70 & 3.15 & -0.16 & 3.90 & -1.35 & 151.41 & 5.09 & -1.26 & 2.29 & -1.00 & 0.86 & 2.55 & 0.10 & & \\
\hline 53.91 & 2.42 & -1.16 & 1.71 & -0.97 & 0.82 & & & 3.40 & -1.30 & 152.89 & 5.13 & -1.14 & 2.31 & -0.95 & 0.93 & 2.40 & 0.19 & & \\
\hline 55.41 & 2.49 & -1.01 & 1.76 & -0.98 & 0.74 & 3.21 & -0.19 & 3.68 & -1.62 & 155.01 & 5.18 & -0.97 & 1.80 & -0.79 & 0.55 & 2.80 & -0.15 & & \\
\hline 56.89 & 2.55 & -1.33 & 1.82 & -1.06 & 0.60 & & & 3.63 & -1.19 & 156.49 & 5.21 & -1.20 & 2.06 & -1.01 & 0.51 & 2.60 & 0.03 & & \\
\hline 56.89 & 2.55 & -1.26 & 1.38 & & & & & & & 158.01 & 5.25 & -1.06 & 2.07 & -0.95 & 0.78 & 2.38 & 0.10 & & \\
\hline 59.01 & 2.65 & -1.27 & 2.02 & -1.08 & 0.85 & 2.89 & 0.07 & 3.32 & -1.25 & 159.51 & 5.28 & -1.40 & 2.01 & -1.26 & 0.61 & 2.50 & -0.13 & 3.27 & -1.59 \\
\hline 60.49 & 2.71 & -1.26 & 2.08 & -1.12 & 0.91 & 3.10 & -0.19 & 3.71 & -1.22 & 161.01 & 5.32 & -1.17 & 2.11 & -0.71 & 0.87 & 2.41 & 0.01 & 2.95 & -1.27 \\
\hline 62.01 & 2.78 & -1.49 & 1.94 & -1.24 & 0.66 & 2.80 & -0.18 & 3.47 & -1.29 & 162.80 & 5.36 & -1.44 & 1.54 & -0.92 & 0.88 & 2.48 & -0.31 & 2.99 & -1.77 \\
\hline 63.51 & 2.84 & -1.43 & 2.08 & -1.18 & 0.84 & & & & & 163.79 & 5.38 & -1.21 & 1.92 & -0.84 & 1.07 & 2.42 & 0.10 & & \\
\hline 63.51 & 2.84 & -1.67 & 1.97 & & & & & & & 165.31 & 5.42 & -1.20 & 2.06 & -1.07 & 1.03 & & & 3.04 & -1.27 \\
\hline 65.01 & 2.91 & -1.53 & 1.72 & -1.26 & 0.54 & & & 3.18 & -1.27 & 167.21 & 5.46 & -1.20 & 2.35 & -0.88 & 1.25 & & & & \\
\hline 66.49 & 2.95 & -1.53 & 1.79 & -1.21 & 0.63 & 2.44 & -0.04 & 3.17 & -1.03 & 168.69 & 5.50 & -1.18 & 2.23 & -0.83 & 1.25 & 2.78 & 0.20 & & \\
\hline 68.61 & 3.01 & -1.32 & 2.12 & -1.27 & 0.75 & 2.35 & 0.17 & & & 170.21 & 5.53 & -1.19 & 1.95 & -0.87 & 1.10 & 2.69 & 0.28 & & \\
\hline 70.09 & 3.05 & -1.44 & 2.05 & -1.20 & 0.72 & & & 3.10 & -1.14 & 171.71 & 5.57 & -1.21 & 2.09 & -0.74 & 0.96 & & & & \\
\hline 71.61 & 3.09 & -1.35 & 1.77 & -1.22 & 0.65 & 2.65 & 0.05 & 3.39 & -1.06 & 173.21 & 5.61 & -1.20 & 2.43 & -0.75 & 1.29 & & & & \\
\hline 73.11 & 3.14 & -1.46 & 1.88 & -1.28 & 0.67 & 2.40 & -0.01 & 3.13 & -1.19 & 174.71 & 5.64 & -1.16 & 1.81 & -0.60 & 0.74 & 2.61 & -0.05 & & \\
\hline 74.64 & 3.18 & -1.41 & 1.84 & -1.25 & 0.81 & 2.23 & -0.03 & 3.06 & -1.39 & 175.70 & 5.66 & -1.22 & 2.25 & -0.86 & 1.08 & 2.81 & 0.22 & & \\
\hline 76.09 & 3.22 & -1.47 & 1.67 & -1.30 & 0.42 & 2.55 & -0.13 & 3.05 & -1.11 & 177.71 & 5.71 & -1.32 & 2.47 & -0.67 & 1.23 & & & & \\
\hline 78.21 & 3.28 & -1.36 & 1.84 & -1.24 & 0.74 & 2.62 & 0.13 & 3.21 & -1.03 & 179.21 & 5.75 & -1.23 & 2.05 & -0.80 & 1.08 & & & & \\
\hline 78.21 & 3.28 & -1.34 & 1.88 & & & & & & & 180.71 & 5.78 & -1.24 & 2.10 & -0.80 & 1.17 & 2.65 & 0.24 & & \\
\hline 79.69 & 3.33 & -1.29 & 1.66 & -1.26 & 0.75 & & & 3.24 & -1.07 & 182.21 & 5.82 & -1.24 & 1.97 & & & & & & \\
\hline 81.21 & 3.37 & -1.58 & 1.83 & -1.29 & 0.86 & 2.74 & 0.33 & & & 183.71 & 5.85 & -1.20 & 2.30 & & & & & & \\
\hline 82.71 & 3.41 & -1.77 & 1.96 & -1.25 & 0.87 & 2.68 & -0.04 & 3.30 & -1.00 & 185.81 & 5.90 & -1.19 & 1.75 & & & & & & \\
\hline 84.21 & 3.45 & -1.48 & 1.96 & -1.43 & 0.73 & 2.40 & 0.15 & 3.08 & -0.87 & 187.31 & 5.94 & -1.18 & 2.01 & & & 2.44 & -0.13 & & \\
\hline 85.69 & 3.50 & -1.47 & 1.88 & -1.40 & 0.63 & 2.19 & -0.01 & 2.86 & -1.17 & 188.81 & 5.97 & -1.10 & 2.00 & & & 2.32 & -0.03 & 3.10 & -1.02 \\
\hline 85.69 & 3.50 & -1.76 & 1.57 & & & & & & & 190.31 & 6.01 & -1.13 & 1.99 & & & 2.49 & -0.02 & & \\
\hline 87.81 & 3.56 & -1.73 & 1.71 & -1.48 & 0.73 & & & & & 191.81 & 6.04 & -1.05 & 1.74 & & & & & 2.99 & -1.33 \\
\hline 87.81 & 3.56 & -1.51 & 1.74 & & & & & & & 193.31 & 6.08 & -1.06 & 1.97 & & & 2.14 & -0.15 & & \\
\hline 89.29 & 3.60 & -1.89 & 1.63 & -1.51 & 0.45 & 2.42 & & & & & & & & & & & & & \\
\hline
\end{tabular}

